

\section{DISCLAIMER}

This report was prepared as an account of work sponsored by an agency of the United States Government. Neither the United States Government nor any agency Thereof, nor any of their employees, makes any warranty, express or implied, or assumes any legal liability or responsibility for the accuracy, completeness, or usefulness of any information, apparatus, product, or process disclosed, or represents that its use would not infringe privately owned rights. Reference herein to any specific commercial product, process, or service by trade name, trademark, manufacturer, or otherwise does not necessarily constitute or imply its endorsement, recommendation, or favoring by the United States Government or any agency thereof. The views and opinions of authors expressed herein do not necessarily state or reflect those of the United States Government or any agency thereof. 


\section{DISCLAIMER}

Portions of this document may be illegible in electronic image products. Images are produced from the best available original document. 


\title{
The Disposal of Spent Nuclear Fuel
}

\author{
Topical Report
}

December, 1979

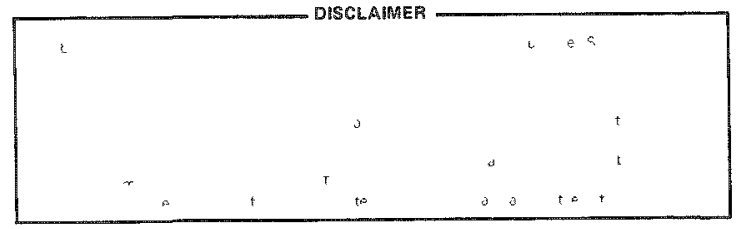

Office of Nuclear Waste Isolation Battelle Project Management Division 505 King Avenue Columbus, $\mathrm{OH} 43201$

This report was prepared by Battelle Project Management Division Office of Nuclear Waste Isolation under Contract No. EY-76-C-06-1830 with the U.S. Department of Energy. 


\section{AOK NOWLEDGMENTS}

This report was prepared by the Office of Nuclear Waste Isolation with contributions from staff at the Basalt Waste Isolation Project and the Nevada Test Site. Martin Molecke of Sandia and John E. Donnelly of Westinghouse provided review and comment. Major contributors were

John Carr, ONWI

C. R. DeLannoy, BWIP

William Pardue, ONWI

Meyer Pobereskin, ONWI

John Wadde 11, ONWI 


\section{TABLE OF CONTENTS}

\section{Page No.}

BACRGROUND 1

SUMMARY

PERTINENT CHARACTERISTICS OF SPENT FUEL 6

WHICH IMPACT ISOLATION

Preset Form, Composition and Geometry 6

Actinide Content 6

Fission Gas 7

Leaching and Chemical Reactions 7

Thermal Energy 8

Criticality 9

Resource Value $\quad 9$

CURRENT KNOMLEDGE ABOUT SPENT FUEL ISOLATION 10

Logistics of Spent FueI Generation and Transfer 10

Characteristics of Nuclear Reactor Fuel 13

$\begin{array}{ll}\text { Packaging of Spent Fuel } & 16\end{array}$

Handling and Emplacement of Packages in the Repository 22

Isolation Behavior of Wastes in the Repository 25

The Economics of Spent Fuel Isolation 28

RESEARCH AMD DEVELOPMENT PROGRAMS 30

$\begin{array}{ll}\text { General } & 30\end{array}$

Waste Package Development Programs 32

Package Criteria $\quad 34$

Waste Form $\quad 34$

Engineered Barriers $\quad 35$

Package Design 35

Verification Testing 35

Repository $\quad 36$

In Situ Testing $\quad 36$

Other Repository Programs $\quad 37$

$\begin{array}{ll}\text { System Integration } & 39\end{array}$

Site Quarification $\quad 40$

IMPLEMENTATION OF SPENT FUEL DISPOSAL 42

REFERENCES

$\begin{array}{lr}\text { BIBLIOGRAPHY } & 50\end{array}$ 


\section{LIST OF TABLES}

Page No.

Table 1. Corrosion Rates of Candidate Alloys 20

Table 2. Summary of Spent Fuel Isolation Problems Which 33

Will Be Addressed in the R\&D Program

Table 3. In Situ Test Programs

\section{LIST OF FIGURES}

Figure 1. Repository and Storage Requirements 12

Figure 2. Nuclear Power Plant Fuel Elements 14

Figure 3. Combustion Engineering Fuel Assembly with an 15 Exploded View of a Single Fuel Rod

Figure 4. Radioactive Decay of PWR Spent Fuel 17

Figure 5. Thermal Power Curves for Typical Spent Fuel 18 Assemblies and HLW Canister

Figure 6. Conceptual Design Incorporating Likely Barrier 21 Elements

Figure 7. Repository for Isolation of Nuclear Waste 23

Figure 8. Boring Type Continuous Mining Machine for Use 23 in a Bedded Salt Repository

Figure 9. NWTS-2 Transporter and Emplacement Concept 24

Figure 10. Composite Bedded Salt/Spent Fuel Rate of 29 Expenditures

Figure 11. Delegation of Responsibility for Nuclear Waste 31

Figure 12. First NWTS Repository Plan for IRG Strategies II and III 


\section{BACKGROUND}

This report addresses the topic of the mined geologic disposal of spent nuclear fuel from Pressurized Water Reactors (PWR) and Boiling Water Reactors (BWR). Although some fuel processing options are identified, most of the information in this report relates to the isolation of spent fuel in the form it is removed from the reactor.

Commercial nuclear wastes have been produced in increasing amounts since the $1950^{\prime} \mathrm{s}$. These wastes are mainly the by-product of the production of power in nuclear reactors. High Level Wastes (HLW) are either unreprocessed spent fuel assemblies or that portion of wastes generated in reprocessing of nuclear fuel elements that contains virtually all of the fission products. In addition, there are other forms of waste such as transuranic wastes (TRU), low level wastes (LLW), mill tailings, and gaseous effluents which will not be further discussed in this report. (1)

Evaluation of technologies for the disposal of commercial highlevel radioactive wastes dates back to 1955. At the request of the U.S. Atomic Energy Commission, a committee of geologists and geophysicists was established in that year by the National Academy of Sciences - National Research Council to study this problem. Subject to a number of caveats, this committee proposed storage in mined geologic repositories, particularly in natural salt formations, as the most promising method for safe disposal of high-level radioactive wastes. (2)

Following this recommendation, the program to develop a commercial waste management system continued sporadically and at a relatively low funding level through 1975. This low level of effort apparently stemmed in part from the perception that stable waste forms could be developed readily and that safe disposal could be easily achieved through the isolation of wastes in a mined repository. Furthermore, the costs were expected to be small relative to other cost elements in the production of power. Until recently, the absence of disposal facilities was not seen as a potential constraint on the use of nuclear energy. The total expendjtures on waste management through 1975 by the AEC and ERDA were $\$ 562$ million. (3) Less than 10 percent of this amount was directed toward commercial waste isolation. Since that time DOE has expended about $\$ 250$ million through fiscal year 1979 for commercial waste isolation studies.

One of the major accomplishments of these early studies and activities was the demonstration of retrievable storage in rock salt which was performed in Lyons, Kansas in 1969. (4) This experiment demonstrated the handiing of spent fuel underground, and provided data on the combined effects of heat and radiation on salt. For several technical and other reasons, this experiment failed to mature into a full-fledged repository. After the abandonment of the Kansas site, ERDA began to fayor surface storage, but this effort was also abandoned in the early seventies. (5) 
In September, 1974 , a draft Environmental Impact Statement (WASH-1539)(6) on the program for developing interim and permanent repositories for high-level and transuranic wastes was issued. This EIS was withdrawn in April 1975 and replaced by a generic impact statement, "Environmental Impact Statement on Management of Commercially Generated Radioactive Waste" issued as a draft in April of $1979(7)$ as part of the NEPA process for the current National Waste Terminal Storage (NWTS) development program.

Concurrent with the preparation of this latter environmental statement, a number of policy reviews and changes related to nuclear waste management were made. In President Ford's October 26, 1976, policy statement, the possibility of a ban on reprocessing was identified. (8) Then on Apri1 7, 1977. President Carter announced that the United States would defer indefinitely all reprocessing of civilian nuclear fuel until both the institutional and technical aspects of proliferation ould be considered. (9) The fundamental reason for establishing this policy was a concern that the widespread separation of plutonium could lead to the proliferation of nuclear weap ons.

As a consequence of this policy, spent fuel from reactors became a candidate for disposal. Accordingly, the DOE program for waste isolation was redirected to reflect this new emphasis, and includes spent fuel as well as processed high-level waste from a reprocessing facility.

A number of significant reviews of the problems and programs in the geological disposal of nuclear wastes were initiated in 1978. The U.S. Environmental Protection Agency issued a report entitled "The State of Geologic Knowledge Regarding Potentjal Transport of High-Level Waste from Deep Terrestial Repositories".(10) The U.S. Geological Survey issued a document, "Geologic Disposal of High-Level Radioactive Wastes - Earth Science Perspectives". (11) The National Academy of Sciences issued "Limitations of Rock Mechanics in Energy Resource Recovery and Development. "(12) The American Physical Society issued the report of the Study Group on Nuclear Fuel Cycles and Waste Management. (13) DOE issued the "Report of the Task Force for Review of Nuclear Waste Management". (14) All of these activities finally led to the establishment by President Carter of an Interagency Review Group on Nuclear Waste Management, which issued a draft report in October, 1978, and a final report on their findings to the President in March, 1979.(1) This IRG report presented numerous recommendations and developed several strategies for the President to consider in preparing a policy statement on nuclear waste management. Among their conclusions was the statement, that: "The IRG finds that reprocessing is not required to assure safe disposal of commercial nuclear fuel in appropriately chosen geologic environments".

In this report, the characteristics of the waste management system and research which relate to spent fuel isolation will be discussed. The differences between spent fuel and processed HLW which impact the waste isolation system will be defined and evaluated for the nature and extent of that impact. What is known and what needs to be determined about spent fuel 
as a waste form to design a viable waste isolation system will be presented. other waste forms and programs such as geologic exploration, site characterization and licensing which are generic to all waste forms will also be discussed briefly to the extent that they impact some aspect of spent fuel disposal.

R\&D is being carried out to establish the technical information to develop the methods used for disposal of spent fuel. All evidence to date indicates that there is no reason, based on safety considerations, that spent fuel should not be disposed of as a waste.

\section{SUMMARY}

Although most of the early waste isolation research was directed toward the disposal of reprocessing wastes, much of the information developed in these studies is directly applicable to spent fuel isolation. Since the emphasis has shifted recently to consideration of spent fuel as a waste form, several pertinent characteristics of spent fuel become most important when considering isolation in a mined geologic repository. Although not independent, these key characteristics of spent fuel are:

- A preset form, composition, and geometry

- A greater actinide content than equivalent HLW

- A long-lived thermal power potential

- Sufficient fissile material content to cause criticality and safeguards concerns

- Fission product gases both free in the plenum and bound in the $\mathrm{UO}_{2}$ matrix

- Leaching and dissolution resistance which is good but preset and which may be less than available with specially processed waste forms, and finally

- A resource value contained in the package materials and possibly in the future - a resource value associated with the actinides.

The consequences of the above characteristics to the design of the repository are under study. The leach resistance of spent fuel is still being determined. Early results indicate it to be about of the same order of magnitude as for borosilicate glass. Fission product gases in the spent fuel may cause some operational safety concerns due to the potential release of mobile radionuclides into the mine ventilation. However, these effects must be compared to the controlled release during processing or the 
reconcentration and disposal if this latter option were considered. Although still not fully analyzed, the criticality issue does not seem to be a major problem because the consequence of such criticalities, if they occurred at a11, would only result in a relatively small localized release of thermal energy. The chances of such criticality events occurring are extremely small.

Spent fuel can be characterized in great detail, though there is often wide variation in characteristics among assemblies. The main causes of variation are the differences in reactor designs and different fuel burnups, all of which influence the ultimate waste packaging. Initially, the spent fuel waste package was conceived as a simple steel canister which was designed to last only a few years in the repository. However, as a result of the Interagency Review Group Report the package is now conceived as a multibarrier containment which will last until the short-lived fission products have decayed to low levels. Multibarriers include the waste form (ceramic pellets and Zircaloy clad), the canister filler (stabilizer), the canister, the overpack, the sleeve, and the backfill.

The long-term isolation performance must be assessed by modeling. Current studies are looking at release of radionuclides due to both natural and man-made processes. The difference between a remository containing HLW and one containing spent fuel stems from the difference in the potential amounts and rates of release of radioactive species. Because the actinides are highly sorbed on geologic media, the difference in actinide concentration causes only small changes in the total predicted health effects. However, since the spent fuel contains about 200 times as much uranium and plutonium than reprocessed waste, the thermal power does not decay as fast as for waste forms which primarily contain fission products. This may have to be accommodated by limiting the number of canisters per acre of mine.

Much of the waste isolation R\&D (for example geologic exploration) is generic to all waste forms. Of the research specifically directed at spent fuel isolation, most relates to either development of the waste package or the in situ testing. The thrust of the packaging program is to fully resolve the issues concerning waste form, criticality, and fission gas disposition, and to design a multibarrier package. The in-situ test program includes tests with both electric heaters and packaged spent fuel. These tests will identify phenomena and provide data which can be used for design and model validation.

Al though considerable information remains to be developed, much is known about the isolation of spent fuel. Construction of a repository is within the capability of current technology once the design criteria are developed. However, these criteria are coupled with the prediction of long-term performance of the repository as a whole which is still considered to be subject to further research and investigation. Handiing and emplacement of waste packages is a straightforward process, and conventional mining technology generally applies to the construction of a repository. Many conceptual repository designs have been developed including several specifically for spent fuel isolation. 
Preliminary estimates of repository costs indicate that a repository containing about 160,000 canisters wil1 cost approximately one and one-half billion dollars (1978 \$) including construction and operation. This cost is relatively insensitive to the waste form. 


\section{PERTINENT CHARACTERISTICS OF SPENT FUEL WHICH IMPACT ISOLATION}

There are certain physical, chemical and thermal characteristic differences between spent fuel and processed high-level waste (HLW) which are important in considering spent fuel for disposal in a mined geologic repository. The effect of these characteristics on the waste isolation system design are described in the following sections.

\section{Preset Form, Composition and Geometry}

Spent fuel has a preset form, composition and geometry. The types and quantities of spent fuel assemblies available for disposal are dictated by the operating history and future of the commercial nuclear power industry. The vast majority of these spent assemblies will be of the PWR and BWR types consisting of spent fuel pins of uranium dioxide $\left(\mathrm{UO}_{2}\right)$ pellets in sealed metal (Zircaloy) tubes held in a geometric spaced array by grids and end plates. The assemblies are of varying lengths (12-15 ft) and cross section depending on reactor model and core type.(15)

The in-reactor operating history of the spent fuel and also its post operations storage history will define the physical condition of the fuel as received for packaging and geologic disposal. The $\mathrm{UO}_{2}$ pellets can suffer structural damage and contain cracks which affect the nature of the surface area and the potential leach rate. Degradation of the cladding can occur during operation and a small percentage of the fuel pins could have cladding breaches -- with resultant fission gas release and the creation of a pathway between the fuel pellets and the assembly external environment. The operating history of the spent fuel assembly also determines its composition and thermal output.(16)

Thus, while spent fuel as considered for geologic disposal has a preset form, composition and geometry, it can also be characterized as having variability in geometry, composition, and condition resulting from its prior history. Utilization of spent fuel for geologic disposal requires a knowledge of this condition and ariability and their potential effects on repository system performance.

\section{Actinide Content}

During reactor operation approximately one-third of the PWR and one-fourth of the BWR fuel assemblies are remo"ed from the reactor each year and become designated as spent fuel. This spent fuel contains about 3 percent fission products as well as transuranic isotopes by weight, the quantity and composition of which are a function of the operating history of the fuel assembly and el apsed time since removal from the reactor(16). The transuranics and fission products affect the thermal output, radiation 
levels, and criticality potential related to the disposal of spent fuel. While the fission products, which are also present in HLW waste forms at the same level as in spent fuel, will have decayed in hundreds of years, some of the transuranic isotopes will remain at significant levels for hundreds of thousands of years. However, the relative concentration of transuranics in spent fuel compared to high-level waste may range from 50 to 100-fold greater as a function of time of decay. The presence of these transuranics in spent fuel extends the time period over which the repository system must provide isolation from the biosphere.

\section{Fission Gas}

Most of the fission products created in the fuel assembly during reactor operation are bound or retained in the uranium fioxide fuel pellets either by a chemical bond or because they are physically trapped in the crystal lattice. A fraction of the gaseous fission products, krypton and xenon, will diffuse out of the uranium dioxide pellets and be restrained only by the Zircaloy cladding encasing the pellets. Some of the volatile fission products, such as iodine, may also be contained in this volume. In addition, the fuel pins were initially pressured with helium to withstand in-reactor external pressures. In spent fuel the internal pin pressures can approach one thousand pounds per square inch.(17) These gases may create a potential problem, particularly during the repository operations period. They represent a highly mobile waste form available for immediate release in the event of a breaching of the fuel cladding and components of the waste disposal package. In addition to potential release of gases and other vol atiles, depending on the mode of cladding failure, sudden release of the fission gas could entrain and release fuel pellet particulate matter. The components of the waste package must be designed to accomodate the increased internal pressure due to the possible release of such high pressure fission gas from the fuel pins. In producing HLW, of course, the gases and volatiles are removed from the solids, and may be collected and stored by several a) ternative processes.

\section{Leaching and Chemical Reactions}

After emplacement of the spent fuel package in the repository, the most likely vehicle for radionuclide release (after fission gas release) from the waste into or through the package system components and into the surrounding geology is intruding ground water. $(18,19,20,21)$ Transport mechanisms via "flowing" water and diffusion mechanisms aided by thermochemical gradients and reactions contribute to the transport of the radionuclides. Therefore, waste form leaching and near-field thermal-chemical reactions are of concern in addressing potential spent fuel waste mobilization. 
Before leaching of the waste form can take place, physical and/or chemical reactions must occur to breach the engineered barriers constituting elements of the waste package. These reactions and subsequent by-products, in conjunction with the thermal and radiation fields, establish the environment in which leaching occurs. The prior spent fuel pellet condition will determine the surface area available for leaching. The chemical environment, radiation level, and thermal conditions will influence the potential degradation of the uranium dioxide pellets(22) to other chemical forms such as $U_{3} 0_{8}$ which might result in leach rates different from those determined for fresh uranium dioxide pellets. Reactions involving the fuel assembly components other than the $\mathrm{UO}_{2}$ pellets such as cladding, grids, end bells, etc. and their subsequent products might also influence degradation of the pellets. Storage or packaging products such as "crud" or free water remaining with the fuel assembly during repository packaging can al so affect reactions taking $p l a c e$ by influencing potential environmental conditions under which leaching would occur. Concurrently, these reaction products in the vicinity of the waste form can influence not only the waste form leach rate but also the sorption effects in the near vicinity of the waste form by either the geology or engineered barriers emplaced as part of the waste package system. Obviously, the effects described above will vary depending on the nature of the waste form and the waste package.

Similar considerations apply to the processed HLW, with some differences in the details associated with the chemical compositions of the two waste forms.

\section{Thermal Energy}

The disposal of spent fuel with its attendant higher content of long-lived transuranic constituents per package as compared to HLW results in a higher total life-integrated thermal input to the geology than would occur from HLW.(23) The thermal output of a spent fuel assembly is determined by its operating history. It decreases in an exponential manner beginning with its withdrawal from the reactor. The thermal output of the fuel assembly in conjunction with the waste package system, geologic conditions and repository design (via areal loading of wastes) will establish the thermal performance of the assembly itself and other aspects of the repository. This, in turn, affects the repository far-field response, near-field reactions, corrosion, waste rock interactions, package component degradation, and leaching rates. Additionally, emplacement of intact spent fuel assemblies implies that increments of projecten thermal loading per package can be varied only by adjusting the emplacement fuel age. With processed high-level waste forms, package thermal output can also be adjusted by varying the amount of waste per unit package. 


\section{Criticality}

A consideration in the disposal of spent fuel in a mined geologic repository is the potential for and consequences of a criticality reaction at some time due to a variety of possible events. The potential for criticality can be divided into three categories: (1) within a package, (2) between packages via package or package array movement and displacement; and (3) through accumulation of fissionable material via selective ieaching, transport and deposition. (24).

Assembly geometry, package fillers and neutron poisons can all be utilized to control single package criticality potential. Criticality is al so influenced by degradation mechanisms for the spent fuel, the long-term effectiveness of neutron poisons, possible waste package movement, and selective leaching and deposition of plutonium and uranium. The potential effects of such criticality events include increased thermal output, additional generated waste products, and potential near/far-field repository impacts. While such events are highly unlikely, the significance of the 200-fold greater concentration of uranium and piutonium in the spent fuel compared to HLW, needs to be assessed further.

\section{Resource Value}

A future decision to dispose of spent fuel assemblies in a geologic repository assumes, by definition, assignment of a zero resource value to the spent fuel and its fissile component constitutents. Resource value in terms of this discussion includes the other potential man-emplaced materials comprising the waste package and the waste emplacement system. The special characteristics of spent fuel may require the utilization of certain man-emplaced components (such as waste package components) which could in the future be considered as scarce or strategic materials. Careful consideration needs to be given to the use of "nonstrategic" materials where possible, given equivalent performance capabilities. Similar considerations apply to HLW disposal. 


\section{CURRENT KNOHLEDGE ABOUT SPENT FUEL ISOLATION}

A considerable amount of knowledge about spent fuel isolation has been derived from theoretical research and from actual in situ tests. Such in situ testing of spent fuel isolation arrays dates back to Project Salt Vault in the 1960 's. (4) While most of the research in the 50 's, 60 's, and early $70^{\prime}$ 's was really directed toward the disposal of reprocessing wastes, much of the information obtained in these programs is also directly applicable to spent fuel isolation. Since the decision to defer reprocessing, the focus of the present waste package and repository R\&D has shifted in order to provide adequate technology for the isolation of spent fuet.

The available information and data indicate that the construction and operation of a geologic repository for the isolation of spent fuel is well within the capability of current technology, once certain design criteria are developed. This is consistent with the findings of the very extensive recent Bechtel work $(24)$. This study analyzed several spent fuel disposal options and found that "All of the spent fuel disposal cases studied are technically feasible and there are no insurmountable technical problems inherent in their implementation". Residual uncertainties, however, with respect to long-term spent fuel performance in (or interactions with) a geologic repository remain. Appropriate tests to resolve these uncertainties will require several years to complete. Data on spent fuel stability are only now beginning to be available.

In this section we will highlight the key current knowiedge about spent fuel disposal. The subsections will deal with the following topics:

- Logistics of Spent Fuel Generation and Transfer

- Characteristics of Nuclear Reactor Fuel

- Packaging of Spent Fuel

- Handling and Emplacement of Packages in the Repository

- Isolation Behavior of Wastes in the Repository, and

- The Economics of Spent Fuel Isolation.

\section{Logistics of Spent Fuel Generation and Transfer}

The amounts of spent fuel received at a repository depend on a variety of factors including:

- The number and sizes of operating reactors 
- The reactor operating characteristics

- The at-reactor storage time

- The availability and capacity of away-from-reactor (AFR) storage

- The availability and capacity of transportation facilities and equipment

- The availability and receipt capability of repositories, and finally

- The influence of the receipt of other waste types on spent fuel receipt.

The number of spent fuel assemblies produced is directly proportional to the number of kilowatt hours of energy produced, and indirectly proportional to the burnup of the fuel assemblies. These factors are probably not controllable by the repository operator. The amount of power produced depends on how many nuclear power plants the utilities build and operate. The burnup is related to the amount of energy produced per ton of fuel. Current designs of nuclear fuel produce about 30,000 megawatt days of energy per metric ton of uranium in the fuel. It is likely that the continued use of the once-through fuel cycle will lead to higher design burnups. This will reduce the number of spent fuel assemblies, but each fuel assembly will contain more fission products and transuranics, have a greater thermal power, and be more radioactive. These factors influence the transportation, the handling, the emplacement, and other aspects of the repository. Certain processing steps such as fuel bundle disassembly, however, could reduce the impact on the repository design by tailoring the package to the repository.

With these basic constraints the repository operator does have some control over the logistics. Current reference designs call for fuel to be aged at least 10 years before it will be accepted at the repository.

The requirements of other components of the waste management system; i.e., the processing facilities, transportation, AFR's, and at-reactor storage will depend upon repository availability. Although several years are required to build storage, processing and transportation facilities, as long as adequate planning continues and is properly implemented, these facilities should be available as required.

The rate at which spent fuel might be shipped to a repository is shown in Figure 1 along with information regarding storage requirements. In preparing this figure early filling of the repository has been assumed to occur. (25) The repository starts operation in 1988 , reactor generating capacity builds to 380 GWe in the year 2000, and fuel is transferred from reactors in as few as 5 years. For the basis used in this calculation the repository is filled in about the year 2001. There are several reports which 


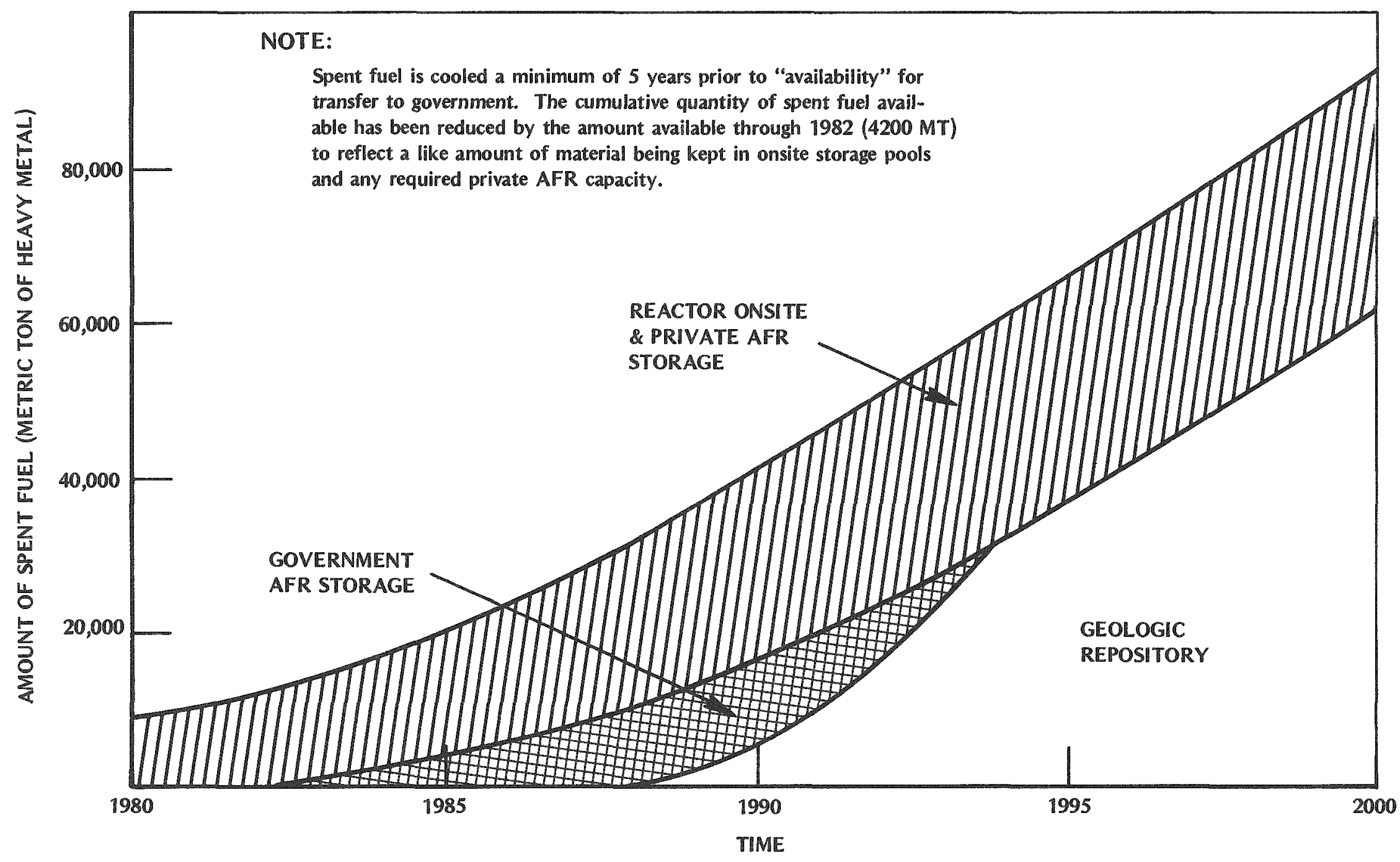

FIGURE 1. REPOSITORY AND STORAGE REQUIREMENTS 
present a more detailed discussion of the amounts of spent fuel which could be sent to the repository. $(7,26,27)$ Present indications are that repository operation will start 1 ater.

\section{Characteristics of Nuclear Reactor Fuel}

Currently the predominant reactor type in the U.S. is the light water reactor; i.e., the pressurized water reactor (PWR) and the boiling water reactor (BWR). Typical fuel elements from both reactor types are illustrated in Figure 2. The elements consist of a bundle of long tubes called fuel pins. The BWR bundle is about $5.5 \mathrm{in}$. square and almost $15 \mathrm{ft}$ long and contains 64 fuel pins. These tubes are made of zironium metal alloy and contain 1/2-in.-long ceramic pellets of uranium dioxide. The PWR bundle is about 8.5 in. square and almost $14 \mathrm{ft}$ long. It contains 289 tubes, about 270 of which are loaded with fuel. Both fuel element types include about 12 ft of active fuel and a gas plenum chamber at the top being about 4 to 8 in. long, making a fuel pin just under $13 \mathrm{ft}$ long. Approximately once a year, one-third of the PWR and one-fourth of the BWR fuel elements are removed from the reactor and replaced with fresh elements because a 1 arge fraction of the fissile (or "burnable") material has been converted to energy and fission products.

The form, composition, and geometry of spent fuel are well known and $c$ an be characterized in great detail. (15) Even though each fuel assembly can be specifically characterized, a wide range in characteristics exists among assemblies. Spent fuel must be appropriately characterized in order to design the package, equipment, and repository and to provide information to enable the prediction of 1 ong-term performance. The size, shape, weight and overall physical form must be known in order to size the canisters, repository rooms, handling equipment, etc. The chemical composition including phase data must be known in order to predict corrosion, diffusion, leaching, and other interactions. The thermal properties including power output and temperature limits must be known in order to determine cooling requirements and the areal emplacement density of spent fuel in the repository. The nuclear characteristics including the radiation field and amount of fissile material must be known in order to design adequate shielding for handiing operations and preventive measures to minimize the potential for criticality.

The size, shape, weight, and overall physical form is well characterized since assemblies are fabricated and operated under carefully controlled conditions. There are a relatively limited number of designs for fuel assembiies, and detailed information (as illustrated in Figure 3 ) is available for each design.

The chemical composition of the fuel is generally well known. The uranium dioxide pellets, zirconium alloy tubes, and the other metal parts are all fabricated of relatively pure materials. Furthermore, al though fission is a statistical process, the process is well defined and the concentration 


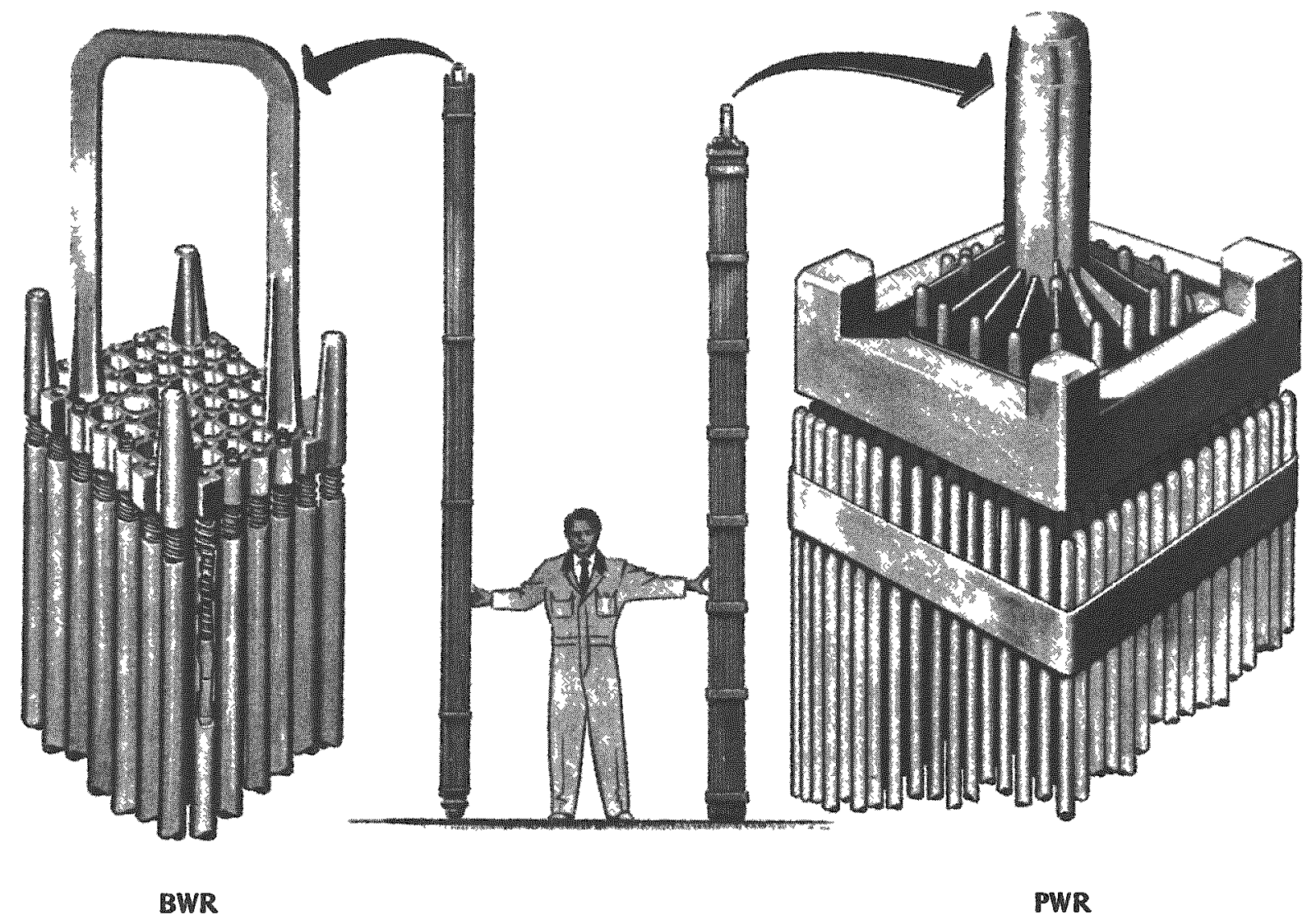

FIGURE 2. NUCLEAR POWER PLANT FUEL. ELEMENTS 

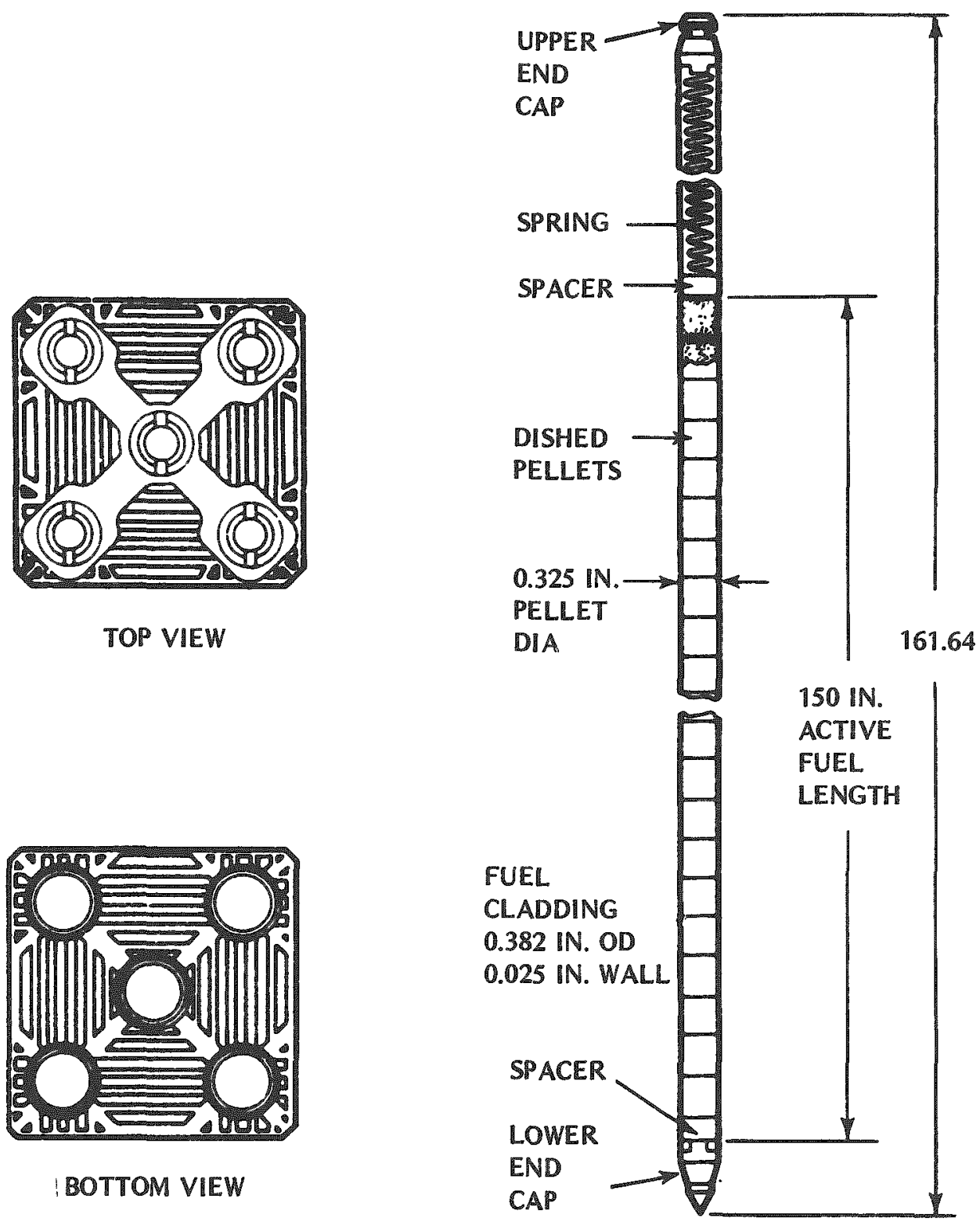

FIGURE 3. COMBUSTION ENGINEERING FUEL ASSEMBLY WITH AN EXPLODED VIEW OF A SINGLE FUEL ROD 
of the many isotopes can be confidently predicted based on the operating history at the reactor. $(7,16,26)$ The isotopic composition relates directly to the thermal power and radiation field associated with the spent fuel. Although the concentrations are known, the chemical compounds and complexes which can form are difficult to fully predict. Similariy, the total amount of volatiles in the spent fuel is easily calculated, but the fraction which may stay trapped in the $\mathrm{UO}_{2}$ matrix is less certain.

An indication of the radiation activity from a spent fuel assembly is shown in Figure 4 . The contribution to the total activity from several important isotopes is indicated. Cesium and strontium are the major contributors in the first two hundred years, and plutonium, neptunium and thorium are major contributors after tens of thousands of years.

Figure 5 shows the variation of thermal power over time for typical PWR and BWR spent fuel assemblies. For comparative purposes, the figure also shows similar data for a canister of vitrified high-level waste. Note that after 10 years the thermal power of a PWR assembly is greater than three times the thermal power of a BWR assembly. Increases in burnup of the fuel could as much as double the thermal power of an assembly. However, whether or not reactors will operate to increased burnups of the fuel will probably depend on whether the once-through fuel cycle, including spent fuel disposal, is implemented.

Even though each spent fuel assembly can be well characterized, there is considerable variation among assemblies because of differences in assembly designs and in operating characteristics (mainly burnup). Such differences, particularly with respect to length and thermal output, could be minimized by some degree of processing of the spent fuel. Some of the alternatives being considered for preparation of spent fuel for isolation include the use of: $(24,28)$

- Furr fuel elements

- Fuel elements with end fittings removed

- Fuel pins from the bundle intact, but separated

- Chopped fuel pins.

These alternatives, and others, are being considered. Disassembled fuel elements provide an opportunity for reduced package size with uniform thermal characteristics.

\section{Packaging of Spent Fuel}

Early in the development of the waste isolation program the function of the "package" was defined as simply providing a manageable unit for handing during the period of time beginning with packaging, through 


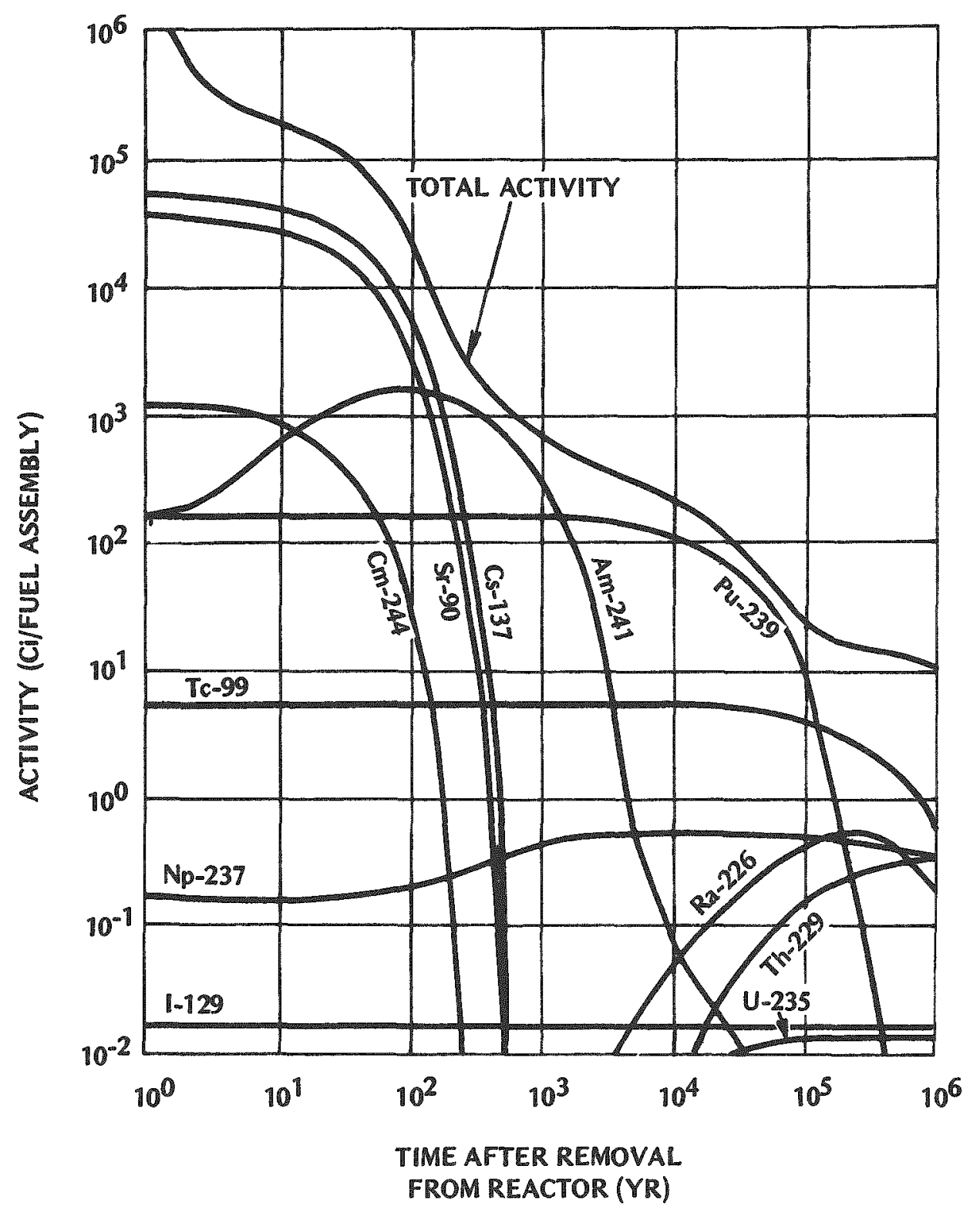

FIGURE 4. RADIOACTIVE DECAY OF PWR SPENT FUEL 


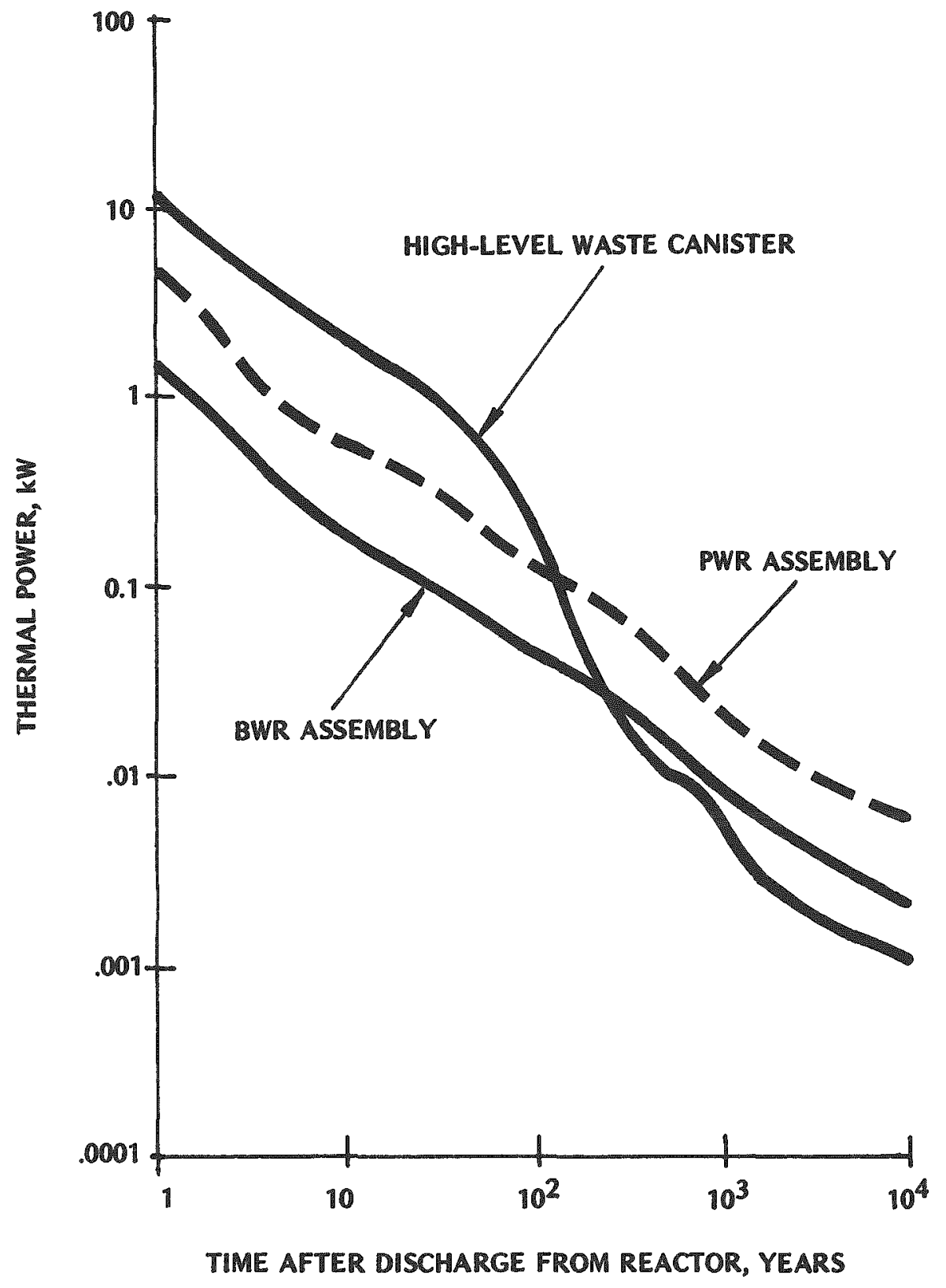

FIGURE 5. THERMAL POWER CURVES FOR TYPICAL SPENT FUEL ASSEMBLIES AND HLW CANISTER

(A PWR assembly contains 0.46 MTHM; a BWR assembly contains 0.18 MTHM; a HLW canister contains the waste from 2.1 MTHM) 
emplacement and repository operation, and ending after closure and sealing of the repository. This approach relied entirely upon the geology for the 1 ong-term containment of the radioisotopes after the useful canister life was exceeded. This kind of package system has been conceptually developed in a number of studies $(7,24,29,30)$. In conceptual form, this package consisted of a single PWR spent fuel assembly or two to three BWR assemblies in unmodified form inserted and sealed into a stainless or carbon steel container. The sealed canister contained air as a filler with perhaps some helium added to allow leak testing of the container following seal welding and possibly to detect and identify canister leakage during repository operation. The canister would be installed vertically in a hole drilled in the floor of the repository and lined with a steel cylinder. The purpose of the liner and annulus gaps is to take up any closure of the geology and prevent redeveloping lithostatic pressures, and to facilitate retrieval of the package during the repository operating period.

As mentioned previously, a number of conceptual designs have been developed directed toward this simple package function. Several designs $(31,32)$ to be used for NWTS demonstrations have been completed and canisters fabricated and fuel packaged into them. Thus, packaging operations for this type of package had to be developed and have been demonstrated.

Several other options related to the disposal of spent fuel have been considered for development of a common package for spent fuel. In its simplest version this involves end bell removal on BWR assemblies to bring package length into line with that used for PWR assemblies.

Largely as a result of the Interagency Review Group Report(1), the role of the "package" in the waste isolation system is now expected to be expanded, whether spent fuel or HLW is isolated. This new package concept would perform a containment function in the intermediate time frame defined as the time from encapsulation of the waste until such time that the short-lived fission products such as Cs-137 and $\mathrm{Sr}-90$ have decayed to essentially innocuous levels. This time frame is approximately 300 to 600 years. The approach presently under consideration to develop a package responsive to this isolation role is to utilize the concept of "Engineered Barriers". The performance goal would be to prevent significant waste rock interaction and subsequent migration of radionuclides out of the package into the immediate rock vicinity for the targeted time period. The package must therefore resist thermal, mechanical, and chemical effects promoting package degradation. Several conceptual design studies $(33,34,70)$ have addressed engineered barrier package concepts. Among these is the Swedish approach which encloses the spent fuel in several very thick 1 ayers of 1 ow reactive metals such as lead and copper. This package concept weighs approximately 18 tons and consists of a 200-millimeter-thick copper canister with the spent fuel potted in a lead filler in the copper canister. An alternative Swedish design utilizes ceramic materials for the package canister. The spent fuel is enclosed in canisters fabricated of aluminum oxide by a hot isostatic compaction process. Aluminum oxide was chosen because it possesses a high integrity over long periods of time as evidenced by its existence in nature as corundum and sapphire. Full-sized canisters have been fabricated. 
Studies at Sandia Laboratory $(70,71)$ have provided experimental data supporting the use of a 300-year canister and of a backfill getter barrier.

Engineered barrier package design efforts (33) in the U.S. to date have primarily emphasized systems studies of the incentives for engineered barriers, the development of performance criteria delineating how the package must perform in the repository isolation system, and the development of expected repository environmental conditions under which the package must perform. Conceptual approaches to the package design include the following package components: (1) the waste form, in this case spent fuel assemblies: (2) a canister filler material to resist package crushing as well as maintain waste geometry and inhibit corrosion: (3) a canister for containment utilized during emplacement and to provide retrievability: (4) a liner to resist 1 ithostatic pressures, enhance retrievability, and retard canister moisture exposure; (5) backfill to repel or absorb water and sorb escaping radionuclides. Figure 6 shows a schematic cross section incorporating these elements.

Material performance studies (71) have been conducted to obtain preliminary information on potential materials for these package design components under conditions which are more severe than expected $n$ a geologic repository. Tabie 1 ists corrosion rates $(71)$ of candidate canister and overpack alloys for the spent fuel burial canister. Under the conditions shown, without protection by other package components, it apparently requires

TABLE 1. CORROSION RATES OF CANDIDATE ALLOYS

\begin{tabular}{|c|c|c|c|c|}
\hline \multirow[b]{2}{*}{ Alloy } & \multicolumn{2}{|c|}{$\begin{array}{l}\text { Oxygenated Solutions at } \\
482 \mathrm{~F}, 1020 \text { psi(a) }\end{array}$} & \multicolumn{2}{|c|}{$\begin{array}{l}\text { Deoxygenated Solutions at } \\
482 \mathrm{~F}, 725 \text { psi }\end{array}$} \\
\hline & $\begin{array}{l}\text { Brine A } \\
\text { (in./yr) }\end{array}$ & $\begin{array}{l}\text { Seawater } \\
\text { (in./yr) }\end{array}$ & $\begin{array}{l}\text { Brine A } \\
\text { (in./yr) } \\
\end{array}$ & $\begin{array}{l}\text { Seawater } \\
\text { (in./yr) }\end{array}$ \\
\hline 1018 Mild Steel & 0.27 & 0.43 & 0.067 & 0.016 \\
\hline Copper & 0.047 & 0.20 & 0.0028 & 0.0020 \\
\hline Lead & 0.047 & 0.039 & 0.016 & 0.012 \\
\hline 90-10 Cupronickel & 0.016 & 0.028 & 0.0055 & 0.0028 \\
\hline SS-Ebrite 26-1 & 0.0094 & - & 0.0055 & 0.00020 \\
\hline Inconel 600 & - & 0.0039 & 0.00035 & 0.00020 \\
\hline Ticode 12 & 0.00016 & - & 0.000024 & 0.00020 \\
\hline Zircalloy-2 & - & - & 0.00039 & - \\
\hline
\end{tabular}

(a) $\mathrm{O}_{2}=600 \mathrm{ppm}$ in Brine A and $1750 \mathrm{ppm}$ in seawater. 


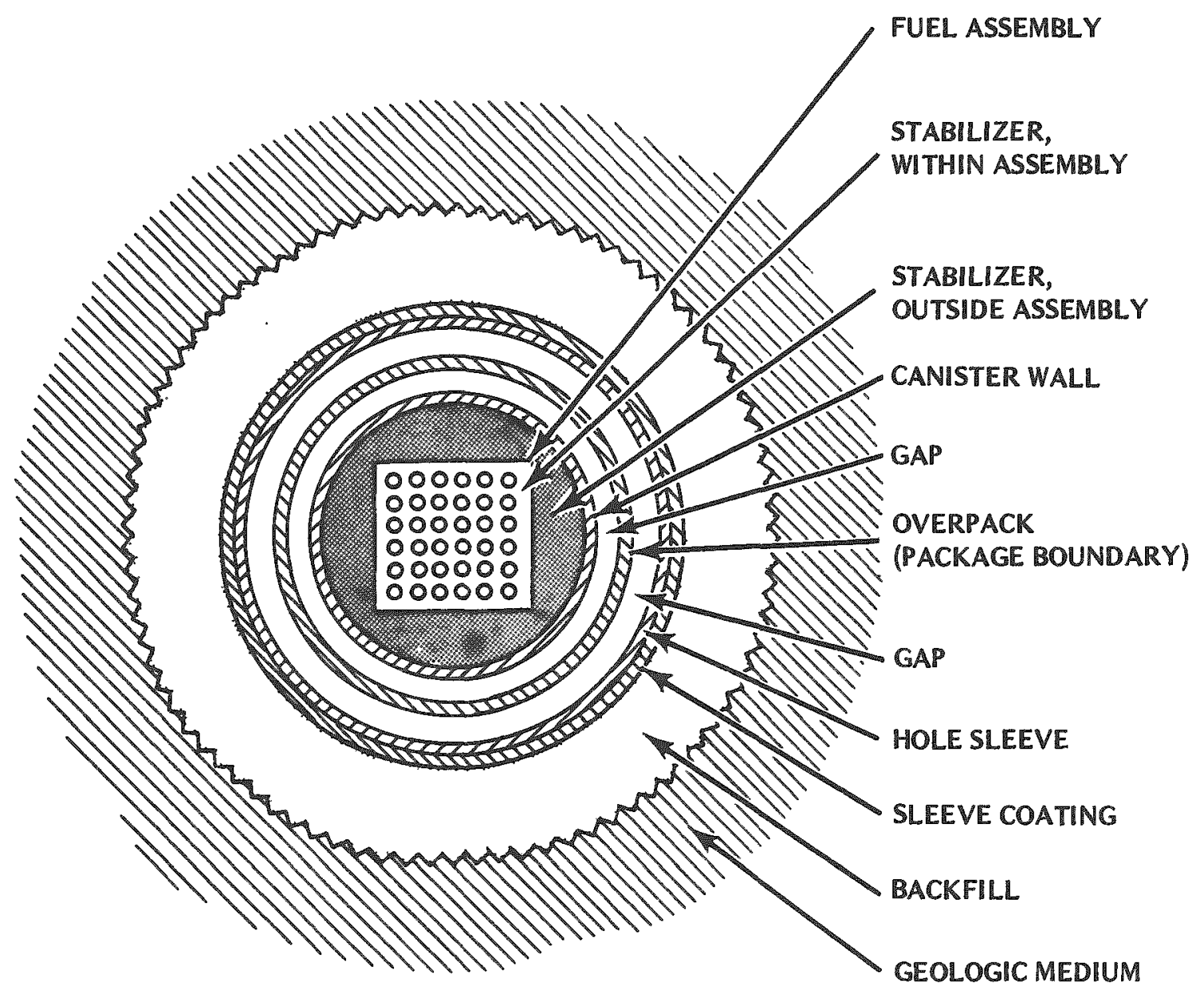

FIGURE 6. CONCEPTUAL DESIGN INCORPORATING LIKELY RARRIER ELEMENTS 
fairly exotic materials to achieve long-term integrity of the container. (This applies only to repositories in salt. For repositories in other media with more benign groundwaters common materials can be utilized.) It should be noted that Zircaloy, which is the cladding surrounding the fuel pellets, is indicated to have excellent corrosion resistance in deoxygenated brine. Studies have been conducted (24) analyzing the relative merits of package internal canister fillers of solid or granular composition. A refined predictive computer model (17) of spent fuel pin surface temperature has been developed to assist in package design activities. Expected repository conditions for a domal salt repository(35) have been developed and conditions for other geologic media are under development. Interim package performance criteria are presently being developed.

\section{Handling and Emplacement of Packages in the Repository}

The handling and emplacement of spent fuel is a known technology and is relatively straightforward. A limited number of shipping casks are currently available. (36) Waste canister unloading, handling, and transfer by industrial-type machines are both feasible and economical. Proven and conventional mining methods $c$ an be used to construct a repository. The current status of repository design and construction was summarized in the conclusions to a multiyear study to prepare the conceptual design for a spent fuel repository in bedded salt. This study by Kaiser Engineers (29) concluded that "... with the given criteria and constraints, it is feasible to build a repository to store 10-year-old spent fuel in bedded salt..." This statement means that although the design of the mine, facilities and equipment can be accomplished at present, the repository's long-term performance is an issue which still needs further assessment.

Conventional mining technology generally applies to the construction of a repository. However, a repository differs from a conventional mine in several respects:

- The objective is to bury material rather than to remove ore

- The radioactive wastes add thermal energy to the geologic formation

- The mine extraction ratios are much lower.

A sketch of a conceptualized repository is shown in Figure 7 . Note that the transporter is similar to readily available equipment. Similarly, the mining machine shown in Figure $8 \mathrm{can}$ be purchased today. Even the emplacement machine shown in Figure 9 is not very different from currently available equipment.

Over the years several repository designs have been developed. Among these is a detailed conceptual design for the disposal of spent fuel in 


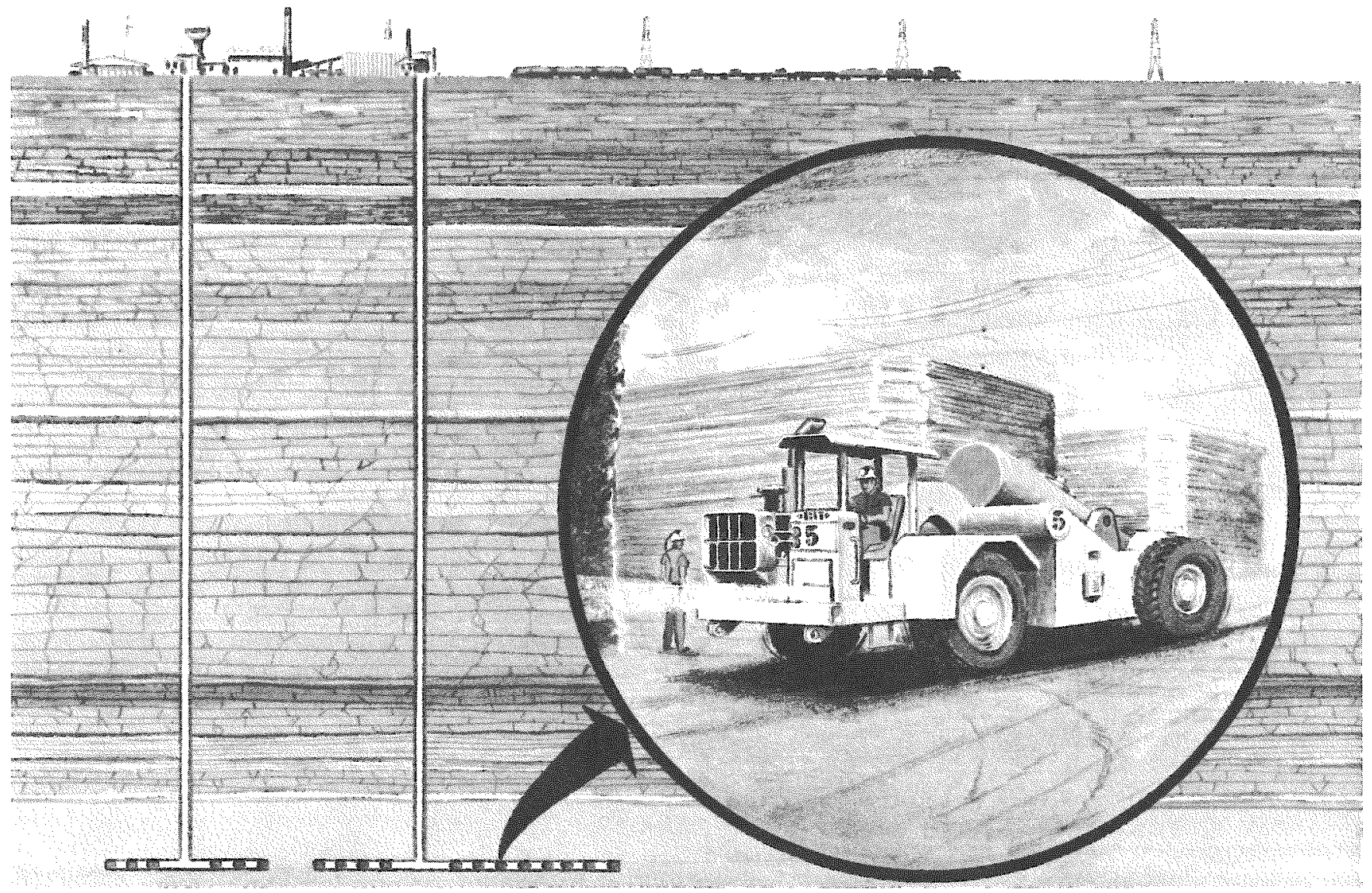

FIGURE 7. REPOSITORY FOR ISOLATION OF NUCLEAR WASTE

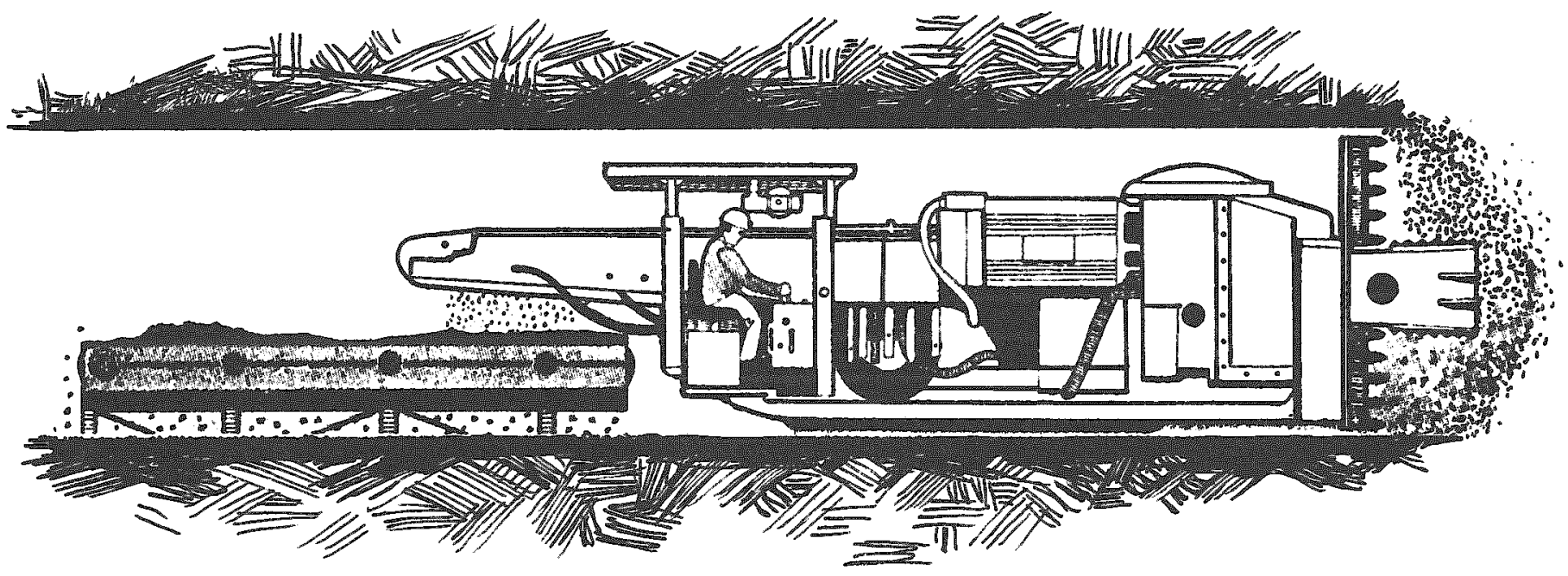

FIGURE 8. BORING TYPE CONTINUOUS MINING MACHINE FOR USE IN A BEDDED SALT REPOSITORY 


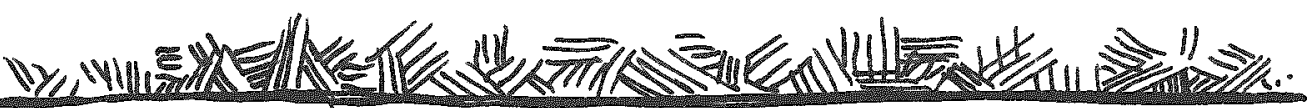

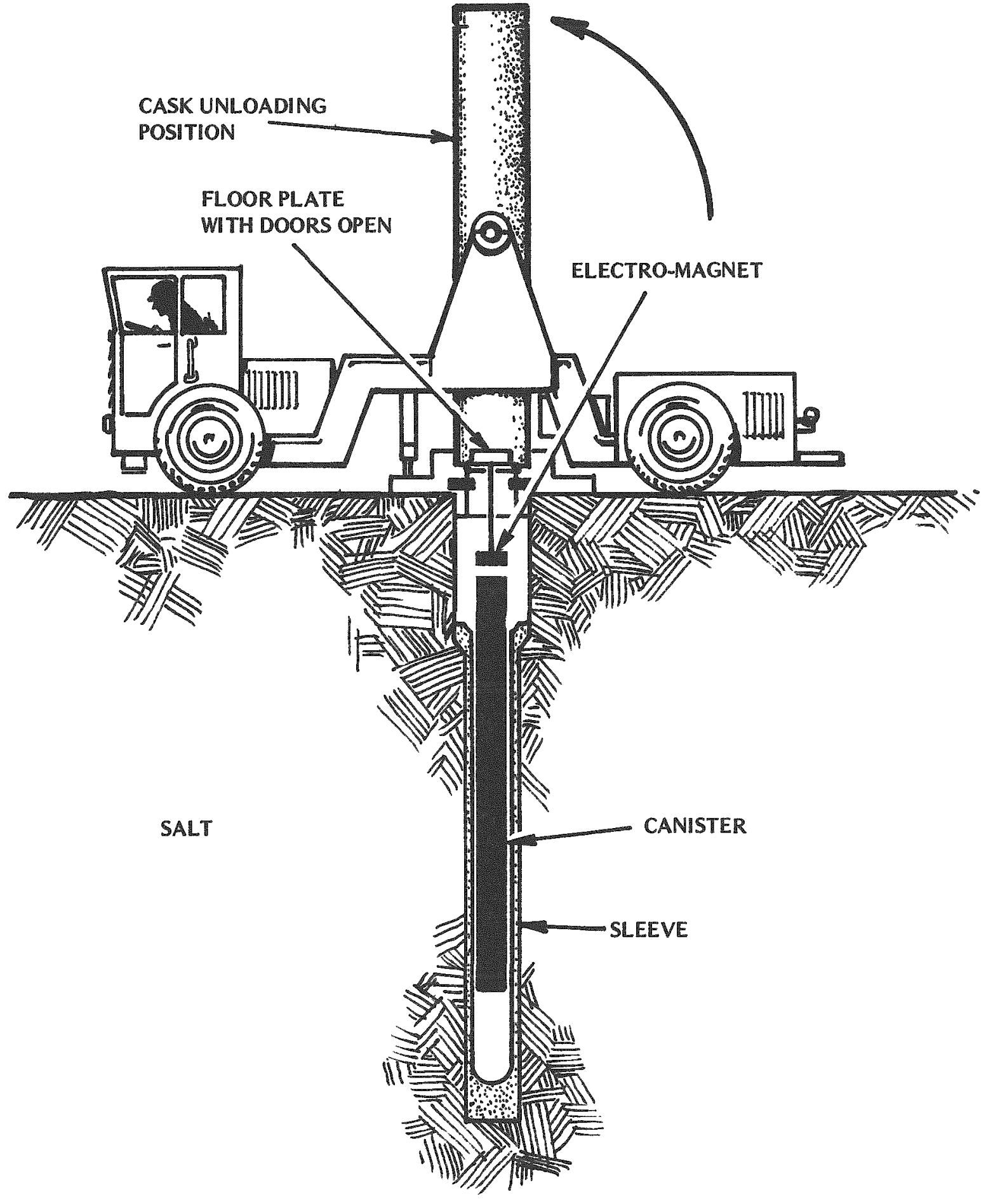

FIGURE 9. NWTS-2 TRANSPORTER AND EMPLACEMENT CONCEPT 
bedded salt prepared by Kaiser Engineers and described in the just-referenced report. A companion study prepared by Stearns Roger Engineering Co. (37) was a conceptual design for a repository in a salt dome which would handle reprocessed high-level waste. The BWIP preconceptual design(38) for a repository in basalt has been completed and the conceptual design has started. Several repository concepts were developed in support of the GEIS.(7) These repositories include concepts for disposal of both spent fuel and reprocessing wastes in several geologic media: salt, basalt, granite, and shale. A Conceptual Reference Repository Design (CRRD) is currently being prepared under subcontract to ONWI to support the Prel iminary Information Report (PIR). This design is for the isolation of spent fuel in a salt dome, al though the isolation of HLW can al so be accommodated. The Waste Isolation Pilot Plant (WIPP) (39) is a repository for transuranic contaminated wastes generated in defense programs. Al though these TRU wastes generate very little thermal power, much of the WIPP design information can be related directly to a spent fuel repository. (This would have been especially true of information from the spent fuel storage experiment which was once considered as part of the program.)

The designs of the major in situ test projects also provide information applicable to handling and emplacement of spent fuel as well as performance data. These demonstrations include:

- Project Salt Vault(4); emplacement of ETR spent fuel in salt

- Dry Surface Storage(31); spent fuel canisters in concrete shields

- Climax Granite(40); el ectrical heaters

- Avery Island (41); el ectrical heaters in salt

- Near Surface Test Facility(42); currently under construction in basalt

- Salt Test Facility currently in an early planning stage.

- Cooperative programs with Sweden(59) and Germany at Stripa and Asse.

\section{Isolation Behavior of Mastes in the Repository}

There are some differences in the performance of repositories containing spent fuel as compared to a repository containing HLW. Some of these differences between spent fuel and HLW disposal have been addressed earlier in this report. 
Since there has been no experience with a full-scale mined repository for waste disposal and because of the very extensive time period involved, the performance of such a system can best be assessed by modeling. This may be done generically or in relation to a specific site. The "Waste Isolation Safety Assessment Program" (WISAP)(43)* is the ONWI-managed activity under which a model and supporting data for far-field effects were being developed for the NWTS program. There were four tasks in this program: release scenario development, data development for radioactive release rates from the waste form, consequence anal ys is and sorption/desorption studies. Except for the second task the information developed is generically applicable to the mined repository concept. The release scenario pertains to natural events and man-made intrusions of the repository which could initiate the release processes. The nature of the emplaced waste form is essentially immaterial for the purpose of these studies. The sorption/desorption studies establish the behavior of the released radioactive species as they are transported through the geosphere. There is not likely to be any major difference between the radioactive species arising from spent fuel or HLW al though there is about 200 times more uranium and plutonium in spent fuel than in the equivalent HLW. (Approximately 99.5 percent of all uranium and plutonium is removed from HLW in reprocessing and recycled to a reactor.) Similarly, consequence analysis deals with the effect of released radioactive species in the biosphere, and it is unlikely that there will be any manifest difference in kinds of radiological effects. All else being equal then, the difference between a repository containing HLW and one containing spent fuel will stem primarily from the difference in release rates (and amount) of the radioactive species from the two sources. These factors, and some others peripheral to the WISAP program but pertinent to isolation behavior, will be discussed below. It should be noted that a Waste Isolation Performance

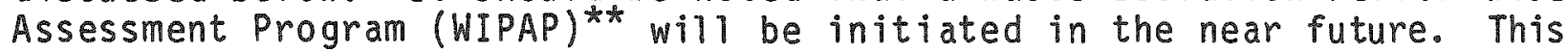
program will include the WISAP tasks, but will be broadened to include the interactions among the waste form, the barriers, the host rock and the groundwaters. The results of these interactions will yield a more real istic mobilized radionuclide source term for input to geotransport models.

The actinide content bears on the radiological effects, the thermal differences, and the potential repository criticality. First, of course, the actinide content provides a major source of radiological effects for the 1 ong term. The 50 to 100-fold greater content of actinides in spent fuel would imply a 50 to 100-fold greater radiological impact. Fortunately, however, the actinides are generally highly sorbed on the geologic media. Consequence analyses for reasonable scenarios show actinide concentrations in the biosphere at levels much bel ow maximum acceptable concentrations. (43) The net result is that the difference in initial actinide concentration between spent fuel and reprocessed HLW causes potential heal th effect differences which are minimal.

* The WISAP program has been restructured and is now designated as AEGIS and WRIT.

** The WIPAP program includes AEGIS and WRIT pius a third projected designated as SCEPTER. 
The actinides are al so the source of the long-term thermal output from spent fuel. Because of these effects the specific loading of the repository must be reduced - compared to HLW - when emplacing spent fuel. (23) The higher initial thermal loading in the HLW package results in higher temperatures in the near term after emplacement in the repository. If this cannot be tolerated by the rock, then the waste concentration in the HLW package may also have to be reduced. This would negate the advantage, usually ascribed to HLW, of higher waste loading per package* and reduction in the overall number of packages. When intermediate level wastes are included, there are more packages from a reprocessing cycle, in any case.

The potential criticality problem stems from the fissile isotope content of the actinides. Again, the 50 to 100-fold higher concentration of actinides is reflected in essentially a 50 to 100-fold greater fissile isotope content. On a per package basis, however, this ratio drops to about 10 because of the higher specific concentration of actinides due to including the wastes from several assemblies in a single package and the higher fissile curium content in the HLW package. Two ameliorating factors come into play: the probability of achieving the condition for criticality is extremely low: a criticality event, if it did occur, would be localized and be self-limiting. Therefore, the risks and radiological impacts on future populations are diminishingly small. (44) Package designs incorporating stabilizers and neutron poisons can help to further minimize this potential problem. (45)

The leach rates of bulk spent fuel $\left(\mathrm{UO}_{2}\right)$ and vitrified high-level waste (borosilicate glass) are generally about the same order of magnitude. The spent fuel is likely to exist, however, in the form of fragmented pellets compared to the monolithic but possibly fractured HLW glass form. On the other hand, there may be some advantage for the spent fuel in retarding the onset of leaching by virtue of the Zircaloy cladding within which the pellets are enclosed. Some other differences need al so to be considered. There is some evidence, for example, that in the case of the spent fuel, U02 pellet dissolution may constitute a major mechanism for putting the material into solution rather than a leaching mechanism. This would tend to put all the species in solution in proportion to their composition in the solid matrix rather than at some selective rate of leaching for different species. One must also consider the chemical interactions which take place among the components of the waste package, the rock and the solution. These components could be considerably different for a spent fuel package compared to a reprocessed high-level waste package so that the leaching or dissolution conditions could very well be considerably different for the same gross repository environment. Consideration of these factors will form the primary focus for study in the WIPAP program.

* One HLW package (borosilicate glass) contains the residual waste from approximately 4 to 6 PWR packages which contain one assembly per package. 
The processed high-level waste form will be free of fission product gas; whereas, the spent fuel waste form will contain its fission product gas. This could give rise to potential problems in the spent fuel repository, particularly with respect to operational safety. Before final conclusions are drawn, it is essential to consider the disposition of the fission gas from the processing operation that produces HLW and the problems related to its disposal. In this connection it should be understood that it is possible to modify the preset form, composition, and geometry of the spent fuel to remove the fission product gas if necessary. other potential advantages for such processing could be the development of a smaller package with a higher specific loading of spent fuel and a better capability for quality control. For instance, one could fabricate packages of a uniform thermal density and minimize the logistic and design difficulties of packaging spent fuel with a widely differing range of burnups in each. Here again one must look to the consequences of such a packaging operation compared to a simple packaging of the spent fuel assembly.

\section{The Economics of Spent Fuel Isolation}

Prel iminary estimates of both repository costs $(29,46,47,48)$ and the charge the Government would impose for storage and disposal of spent fuel have been prepared. Figure 10 shows the cash flow for a bedded salt repository operating at ful1 design capacity. (47) This is for a 2000-acre (of mine workings) repository which contains 160,000 canisters of spent fuel $(68,462$ MTU). The total cost in constant 1978 dollars for engineering, construction, equipment, and operation of the repository is about one and one-half billion dollars. This does not cover the cost of the other components of the waste management system such as storage, transportation, or R\&D.

Plans are to assess a one time charge for all government services (AFR storage and isolation) such that full cost recovery is achieved, including R\&D and the time value of money. In 1978 a preliminary estimate was prepared for a single repository. (49) That study reported a reference charge of $\$ 117 / \mathrm{kg}$ of heavy metal for disposal only and a charge of $\$ 232 / \mathrm{kg}$ for storage and disposal. These values are preliminary and these estimates will be revised in FY 1980. The revision will reflect changes in projected demand as well as the current emphases on regional repositories and technical conservatism. 


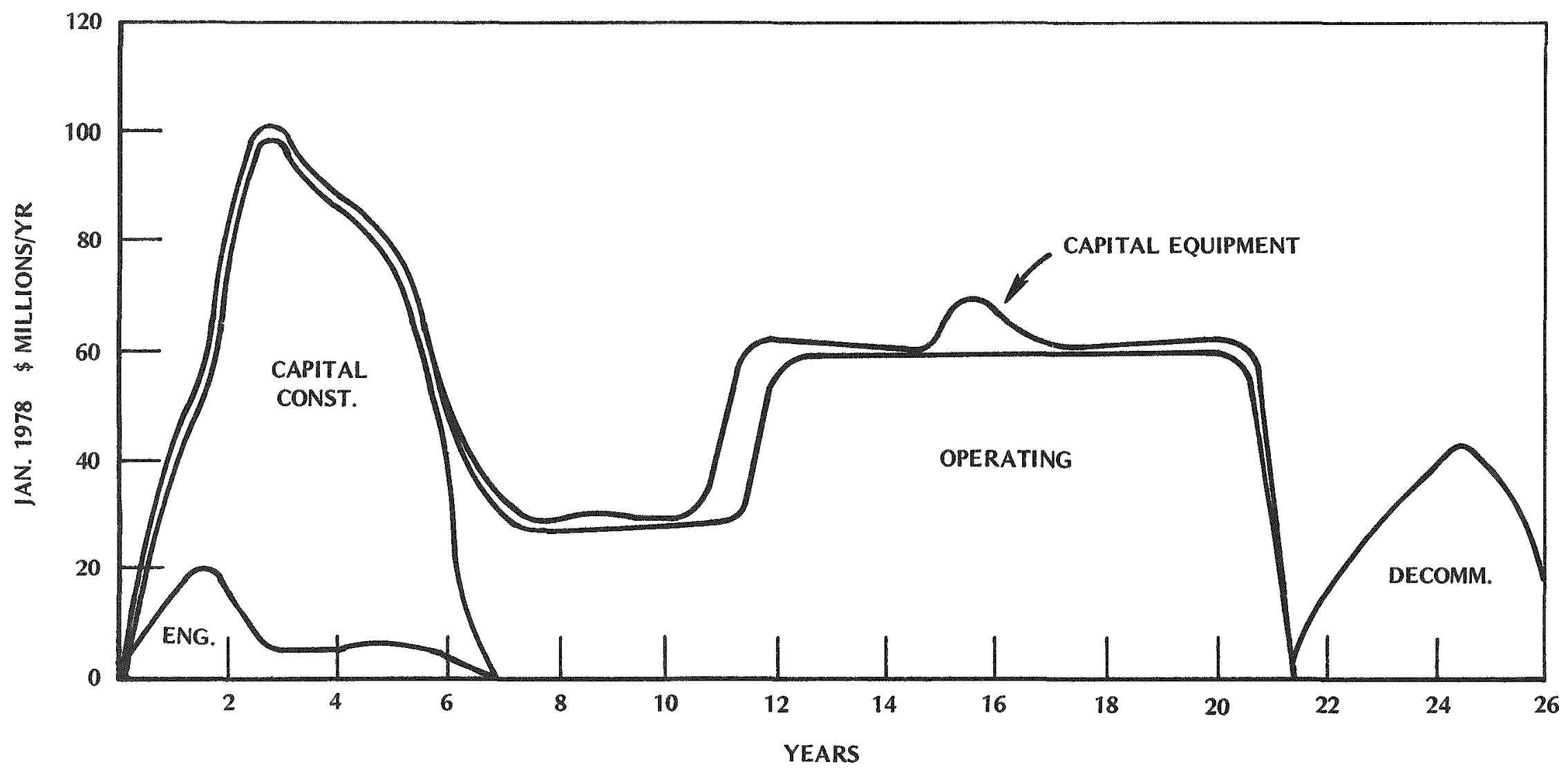

FIGURE 10. COMPOSITE BEDDED SALT/SPENT FUEL RATE OF EXPENDITURES 


\section{RESEARCH AND DEVELOPMENT PROGRAMS}

\section{General}

The research and development for the geologic isolation of spent fuel is being directed by the U.S. Department of Energy's Office of Nuclear Waste Management. (50) As shown in Figure 11, the responsibility for geologic isolation research is shared among four lead contractors. The office of Nuclear Waste Isolation (ONWI) is responsible for the overall direction and coordination of the technology programs supporting the National Waste Terminal Storage (NWTS) effort.(51) In this role, ONWI has responsibility for research and development which will provide data on a wide range of repository sites and designs including support to the other three projects. The Basalt Waste Isgl ation Project (52) and the Nevada Nuclear Waste Storage Investigation (53) will provide evaluation of the Hanford, Washington reservation and the Nevada Test Site respectively to determine if they are suitable for a repository. The BWIP program encompasses both in situ testing and facility engineering in addition to geologic exploration. The NNWSI is currently devoted to geologic exploration, in situ testing, and packaging studies at EMAD. The waste Isolation Pilot Plant program $(54)$, which is not a part of the NWTS program, is to provide a facility intended for the long-term isolation of defense transuranic contaminated wastes and for in situ experimental studies with defense high-level waste. The WIPP facility is planned as a mined geologic repository in bedded salt in the Los Medanos region of New Mexico.

Each of the programs has its own program plan which describes the research and development in terms of their own organization and work breakdown. However, in order to summarize and focus the discussion on R\&D for spent fuel isolation and to obtain an appropriate overview, the following breakdown will be used for discussion:

- Waste Package Development Program

- Package Criteria

- Waste Form

- Engineered Barriers

- Package Design

- Verification Testing

- Repository

- In Situ Testing

- Other Repository Programs

- Systems Integration

- Site Qualification.

This breakdown which crosscuts the entire Spent Fuel Program represents a somewhat abbreviated version of program descriptions used in other budget and 


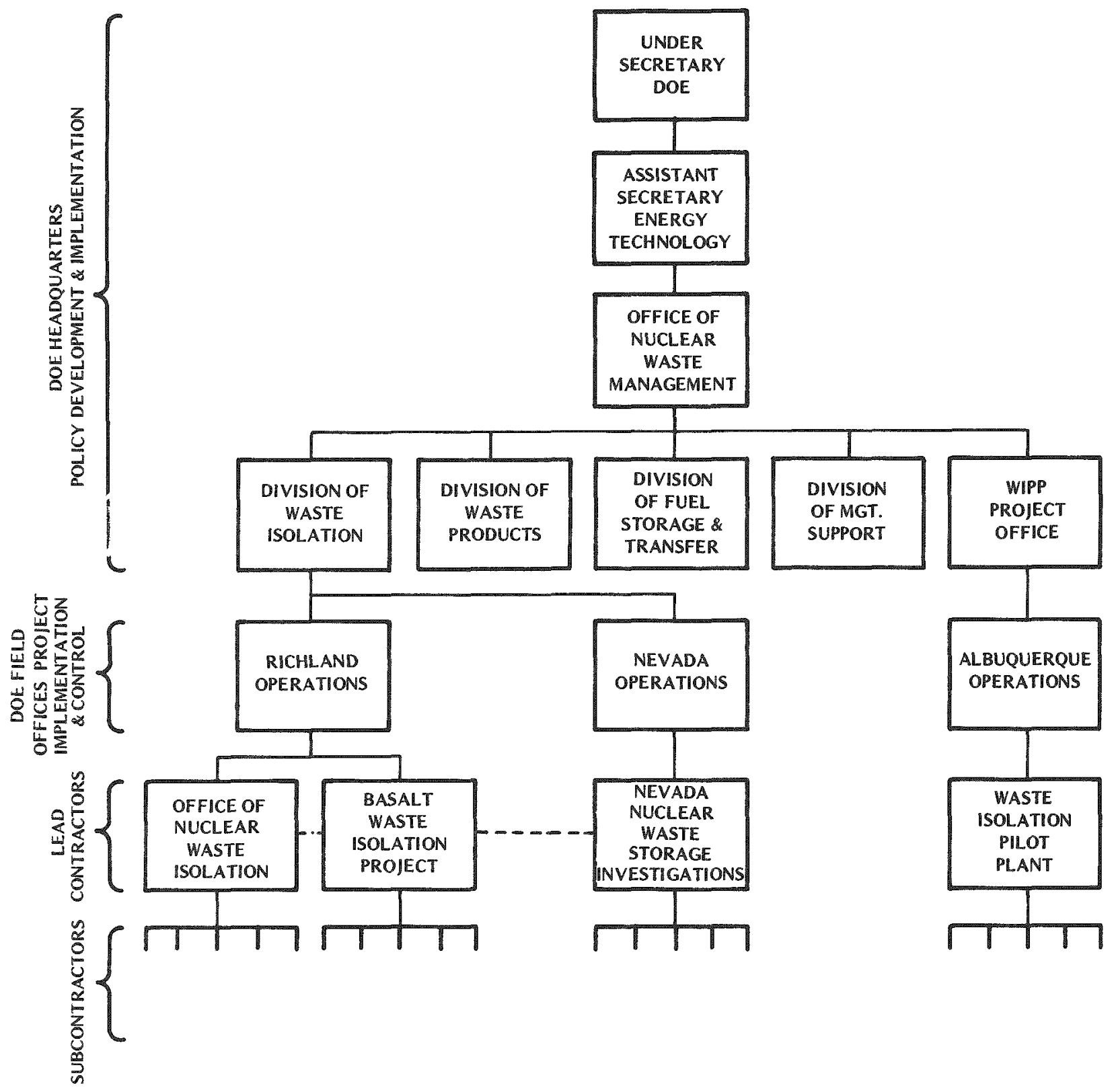

FIGURE 11. DELEGATION OF RESPONSIBILITY FOR NUCLEAR WASTE MANAGEMENT-DECEMBER 1979 
program documents. (55) While many of the programs are generic, the major program content specific to spent fuel isolation is part of the Waste Package programs.

The Repository Programs are less affected by the specific waste form because, ultimately, the repository must perform simil ar functions regardless of the waste form. Since design is an iterative process, repository design can start before the waste package design is complete. However, final repository designs must obviously be consistent with a variety of package designs. Similarly, much of the overall performance assessment can proceed based on a generic or typical waste form since many of the processes are the same or quite similar and only the magnitude of the consequences will depend on the characteristics of a specific waste form.

The System Integration Programs provide definition of requirements, describe the impact of the overall system licensing activities, and analyze the system and subsystem interfaces. The licensing plan, the criteria, and other system integration activities all emphasize the isolation of spent fuel. However, other waste forms such as defense waste are al so addressed as part of system integration. Finally, the Site Qualification Programs are almost completely generic to all waste forms. For example, the geologic exploration program is qualifying sites for hazardous wastes, whether the waste form is spent fuel, high-level waste glass, or any other form.

Table 2 presents a summary of the technical problems stemming from the differences between spent fuel and HLW as waste forms which provide the basis for the studies being performed in the above R\&D programs. In order to fit in with NWTS development schedules based on IRG Strategy III(73), these problems must be resolved in the time frame indicated in the table. (Strategy III provides that only mined repositories would be considered for the first facility and that 3 to 5 geologic environments would be examined.)

\section{Waste Package Development Programs}

The Waste Package Development Programs include the activities to develop the nuclear waste package which is emplaced in the repository. These include the development of criteria, development of requirements for the waste form, the engineered barriers development, and package design.

Package design efforts will be coordinated through the formulation of a package development program plan (in preparation) which will delineate activities and schedules to develop a package which is responsive to IRG recommendations, packaging criteria, and repository reference conditions. The plan will identify $R \& D$ studies in the areas of materials and materials interactions and performance. Al so included are interfaces with all elements of the waste management system. 
TABLE 2. SUMMARY OF SPENT FUEL ISOLATION PROBLEMS WHICH WILL BE ADORESSED IN THE R\&D PROGRAM

Resolution Date Necessary to Meet Current Repository Schedule (Strategy III)

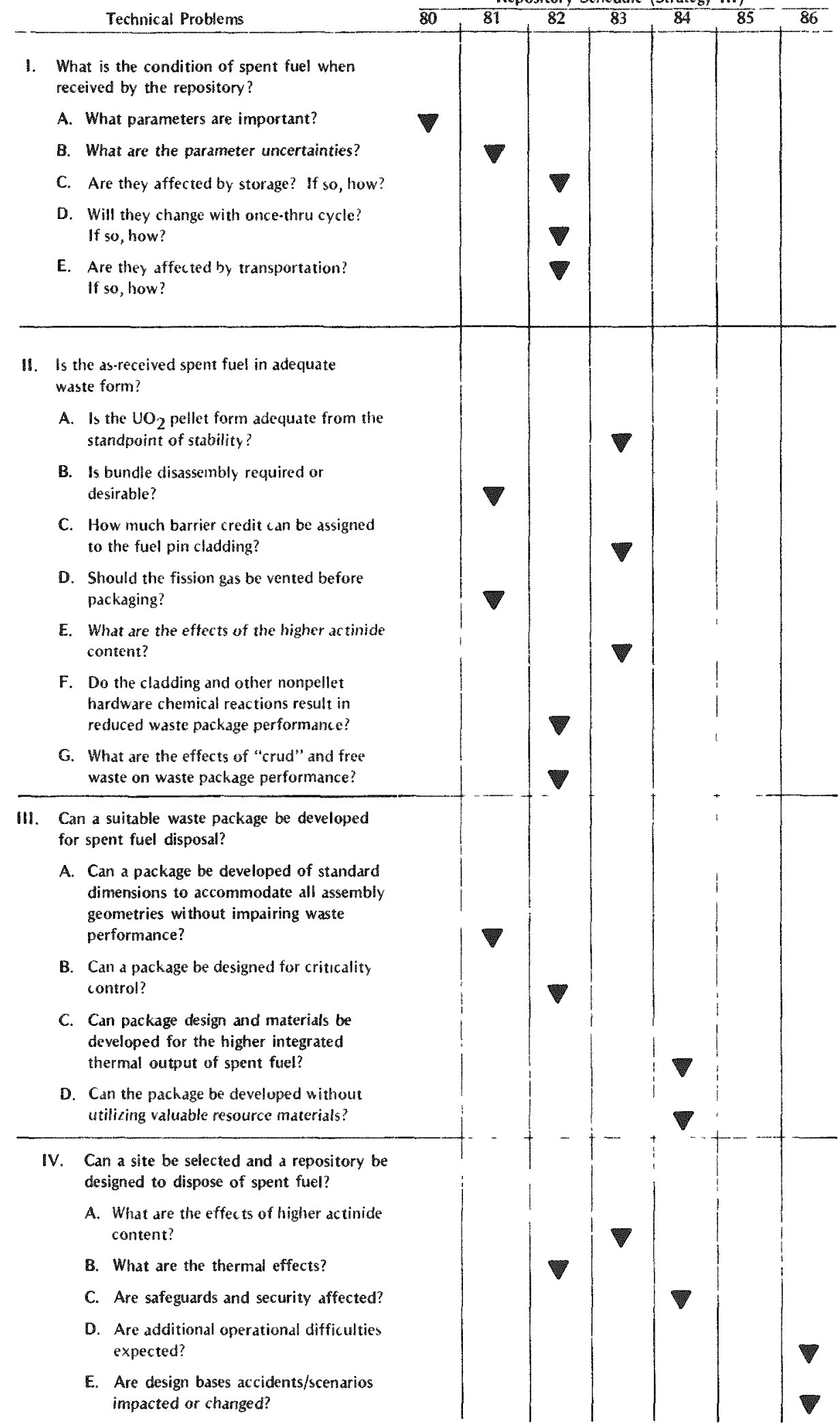




\section{Package Criteria}

The waste package criteria are being developed as part of an integrated program which includes package, repository, and site criteria. Current ONWI efforts cover criteria that are applicable to all waste types, including spent fuel and reprocessed waste forms such as high-level waste, remote- and contact-handled transuranic waste, and cladding hulls. Waste package performance acceptance depends on the design criteria that involve consideration of the requirements associated with specific waste types. In developing technical bases to support these criteria, considerations unique to spent fuel are planned to be addressed in such areas as isolation requirements, fuel form modification and additions, canister dimensions and shielding, fission-gas release, retrieval, temperature limitations, and criticality.

Preliminary Radioactive Waste Package Acceptance Criteria(56) were developed as part of past programs. The emphas is in FY 1980 will be on the the preparation of a Waste Package Criteria Document.

\section{Haste Form}

These studies relate to the selection and evaluation of stability of the waste form. Many of the studies are directed at understanding the process of radionuclide release from the wastes. One of the projects is specifically concerned with identifying and quantifying the release of radionuclides from ipradiated $\mathrm{UO}_{2}$ fuel elements and synthetic and natural uraninite minerals $(57)$ under conditions of geologic disposal or storage. These measurements will be correlated with the behavior of radionuclides observed in the Oklo natural reactor system. (58) Other studies provide a further characterization of spent fuel. These studies are expected to lead to a determination of the processing which may be beneficial for spent fuel isolation.

The major thrusts of the FY 1980 waste form programs are to:

- Resolve the criticality issue

- Resolve the fission product gas issue

- Resolve the physical form issue

- Evaluate the radiotoxicity issue

- Expand leaching studies to include the effect of barriers, and,

- Implement the integration of all waste material programs. 


\section{Engineered Barriers}

The emphasis on engineered barriers is a relatively new thrust in the program. Current R\&D activities are evaluating filler, canister, overpack, and backfill materials which help isolate the waste from groundwater -- thereby minimizing or delaying the migration of radionuclides once leaching has occurred. These include studies of impermeable materials, ion-exchange media, and desiccants. The major thrusts of these programs are to:

- Define concepts and incentives for engineered barriers

- Initiate the ONWI Barrier Materials Development and Integrate the Materials Testing Programs

- Design Conceptual Packages with Barriers.

\section{Package Design}

The objective is to design, develop, and qual ify waste packages for all waste forms intended for disposal in the geologic repository. The spent fuel packaging study is divided into work which supports experimental package development and work which supports the ultimate repository package.

The experimental program will provide packaging, packaging support and engineering test support in the area of spent fuel waste package development and all NWTS experiments and demonstrations. The EMAD facility at NTS has been modified and is being maintained to provide spent fuel experimental packages to various NWTS experiments and demonstrations. In support of these tests a standard canister design for NWTS demonstrations will be prepared.

It is $p l a n n e d$ that $F Y 1980$ activities will concentrate on developing conceptual approaches to the multibarrier package for spent fuel and high-level waste which are consistent with IRG criteria and repository conditions. The planned activity calls for the development of a performance description for the package and its multibarrier components and the identification, where possible, of candidate materials for these components.

\section{Verification Testing}

Conditions to be experienced in each medium for each type of waste package that is designed will be identified and appropriate testing to validate the design will be performed. 


\section{Repository}

The repository R\&D activities include criteria development, near-field performance and in situ testing, as well as the repository and equipment design. There are also programs including the rock technology, the shaft sealing, and instrumentation and monitoring which are generic to all waste forms and will not be further discussed here.

Since most of the R\&D specific to spent fuel isolation is part of in situ testing, only those activities will be discussed separately.

\section{In Situ Testing}

The objective of in situ testing activities is to provide the required technology data base for assessing the validity of analytical models and predicting the behavior of nuclear wastes located in various geologic systems.

The capability to predict the consequences of introducing a heat source (i.e., spent fuel) into a virgin rock mass is a basic requirement in the NWTS program. The requisite technology is being developed in several major programs. In one program $(41)$, heated canisters have been $\mathrm{placed}$ in the Avery Is] and Salt Mine to secure thermomechanical and geothermal response data. Brine/canister and brine/host salt interactions are being measured. This work will provide numerical simulation support for generic repository conceptual designs.

In a second program(59), in situ heating tests are being performed in the stripa granite deposit in sweden to obtain data on induced temperatures, stresses, strains, displacements, and geochemical changes. The program includes an assessment of the applicability of different surface, subsurface, and borehole geophysical techniques in characterizing the fracture system in a granite body, as well as laboratory work directed toward gaining an understanding of the hydraulic, thermal, and rock mechanics behavior of the fractured rock mass. Again, the results will be applied in analytical modeling of repository conceptual designs.

The in situ test program in the $C l$ imax granite $(40)$ on the Nevada Test site is to demonstrate the overall feasibility of safe and reliable storage of spent fuel assemblies in a deeply buried granitic site followed by retrieval after a period of years. The experiment is designed so that maximum rock temperatures will be produced in an accelerated manner, in about one year rather than about 30 years which would be required in a repository. 
The Conasauga(60) and Eleana(61) shale tests are to assess the thermal and mechanical responses of these media to thermal inputs representative of spent fuel or other high-level nuclear waste. These tests will also try to identify any phenomenological surprises which may result from heating the shale.

It is proposed to expand the Near-Surface Test Facil ity (NSTF) (42), now under construction, to provide a testing area to demonstrate the safe storage of nuclear waste material in basalt. The Phase II NSTF tests will complement the Phase I studies, already underway, which use artificial heat sources (electric heaters) to simulate the thermal impact of placing heat-generating nuclear wastes in basalt.

The Phase II tests will examine if actual nuclear waste material $c$ an be stored in an underground basalt environment in a similar geometrical 1 ayout as proposed for a full-scale repository. The tests have been designed to provide a demonstration of safe handing and storage.

A Salt Test Facility (STF) is planned for development in order to conduct tests and experiments to support the timely development and Ticensing of a nuclear waste repository in salt. This program will emplace HLW forms including spent fuel in a candidate 1 ithology to examine radiolysis, brine migration, thermal deformation corroboration, and chemical-physical interaction. Migration rates of radionuclides around a waste canister, in drifts, shafts and boreholes, will also be examined. Integral to these experiments will be the demonstration of equipment and methods to emplace and retrieve various spent fuel and HLW packages integral to the above waste/rock interaction and waste transport experiments.

In the meantime, information on some of the above topics will be provided from the joint U.S./Federal Republic of Germany cooperative experiments in the Asse Salt Mine. Experiments include gas and brine migration, waste/rock interaction, and advanced in situ backfill.

The purposes of the various in situ test programs are summarized in Table 3. Although spent fuel will be used as the radioactive source in these tests, many of the results will be applicable to all high-level waste forms. The in-situ testing needs are described in more detail in the NWTS In-Situ Test Needs Workshop. (62)

\section{Other Repository Programs}

The other repository activities include development of repository criteria, repository equipment technology, repository design, and near-field performance evaluation.

As discussed earlier, preliminary conceptual repository designs have been developed for the disposal of intact spent fuel assemblies in salt formations. Although most of this work was done for bedded salt, it is 
TABLE 3. IN-SITU TEST PROGRAMS

Program

Project Salt Vault

Stripa Granite

Avery Island

Climax Granite

Conasauga Shale/

Eleana Shale

Basalt Near Surface

Test Facility

Salt Test Facility

Asse Salt Mine

\section{Purpose}

Emplace ETR spent fuel in salt to

- demonstrate waste handling equipment and techniques

- analyze gross effects of radiation on salt properties

- analyze radiolytic production of chlorine

- provide data on plastic flow of salt

Provide thermomechanical response and fracture flow data for granite

Provide data on thermomechanical response, brine migration, backfill consolidation, and fracture healing of salt using electric heaters

To determine feasibility of storage of spent fuel assemblies in granite with retrieval after several years

To examine thermomechanical interactions in near surface shale deposits both above and below the water table

Phase I will use heaters to simulate the thermal impact of nuclear wastes in basalt

Phase II will use PWR spent fuel to demonstrate handling and storage in a geometrical layout similar to a full scale repository

To provide data using nuclear wastes in some experiments to provide data on near field waste/rock interaction, near field waste transport, and handling and retrieval

To provide data on brine and gas migration, waste/rock interaction, and backfill performance

\section{Status}

Completed

Planned completion in FY 80

Thermomechanical will complete in FY 80. Others complete by FY 82

Start fuel emplacement in Jan. 1980

Tests complete in FY 79; reports in FY 80

Excavation started in FY 79

Feasibility decision deferred till 1981

Feasibility and site recommendation being reviewed by DOE-HQ

Some experiments completed, plans for future bilateral agreement experiments being finalized 
generally adaptable to dome salt as well. Additionally, preconceptual design activities in support of the GEIS have addressed spent fuel disposal in basalt, granite, and shale formations. Preliminary results indicate that higher storage densities may be attainable in nonsalt rocks than in salt, regardless of the fuel cycle.

Continuing work addresses additional spent fuel disposal options such as the inclusion of on-site packaging capability at the repository. Planned programs include the development of several options for spent fuel waste forms, and an evaluation of the relative merits and cost effectiveness of these options. Additionally, as work continues on alternate geologies, consideration of the special constraints of spent fuel disposal will factor into the details of the nonsalt facility designs.

From the standpoint of repository and equipment design, disposal of spent fuel employs the same principles as disposal of HLW. For the spent fuel waste form, repositories will feature 1 arger equipment and taller headrooms above and below ground, and mine stability problems may arise. Modifications to the spent fuel waste form either by cutting, compaction, or the like, are expected to have only minor influences on the below-ground facilities other than head room requirements. Surface facilities will be affected predominantly by the decision on collocation of packaging and waste form preparation steps.

The near-field performance studies support these efforts by providing data and models for prediction and analys is. planned accomplishments include the preparation of repository environment descriptions for shale and granite to complement the existing one for salt. other work will include modeling of brine migration, and determining interactions among salt, brine, canisters, and waste. chemical and mineralogical interactions between waste materials and shale will also be determined.

The criteria programs will continue development of criteria needed for repository and equipment design.

\section{System Integration}

The System Integration programs include development of system criteria, licensing, support activities, transportation, security and safeguards, subsystem design, socioeconomic analyses, and al ternate concepts development evaluation. These programs analyze the system to assure that spent fuel isolation can be provided by components of the waste isolation system defined in the other programs.

The general criteria document will provide the umbrella criteria for all of the NWTS. This document covers spent fuel and all other waste forms. The draft is currently under review and the final report is planned for FY 1980 issuance. 
In order to obtain a license, the comprehensive technological and information base needed to prepare, document, and defend the Preliminary Safety Analysis Report (PSAR), Environmental Report (ER), and Environmental Impact Statement (EIS) required to obtain a construction permit, must be developed. In addition to these reports ONWI is preparing a Preliminary Information Report (PIR) which is based on spent fuel isolation in a generic salt dome (HLW is also being considered in this report).

The transportation development is carried out in conjunction with the DOE transportation program established at Sandia Laboratories (63) to deal with transportation of spent fuel and all other forms of radioactive wastes. The program activities are very comprehensive and encompass all needs envisioned in assuring the availability of required transportation systems for both defense and commercial programs.

Consideration of spent fuel as a waste form thus has shifted the emphasis in technology and systems development away from reprocessing wastes. Since spent fuel transportation needs are already being addressed under the Spent Fuel Storage (SFS) Programs, the inclusion of spent fuel in the NWTS Program has been accommodated by focusing efforts on development of systems tailored to ship fuel assemblies, canistered or bare, which have been cooled for extended periods ( 10 years or more) at AFR or reactor sites. (This assumes spent fuel packaging is done at the repository.) The shift to consideration of spent fuel as a waste form has nearly eliminated the need for major TRU transportation systems development in the NWTS Program. At present, it is planned to draw on the technology being developed in the defense (WIPP) Program to handle the minimal quantities of TRU wastes anticipated in the once-through fuel cycle.

The security and safeguards programs are to establish the levels of safeguards and security measures required. The socioeconomic programs are to analyze the objectives and bases for governmental policies, criteria, and regulations.

Alternative concepts simply represent alternatives to, or adjunct to, the mined geologic repository. These concepts include but are not necessarily 1 imited to sea bed(64), very deep hole(65), space(66), partition and transmutation(67), and the rock melt concept(68). With the exception of sea bed isolation, these alternatives are in the very early stages of development. Spent fuel is being considered for use in the sea bed and deep hole concepts, but it is incompatible with the space, partition and transmutation, and rock melt approaches.

\section{Site Qualification}

The site qual ification programs include all of the exploration, the earth science investigations, the far-field performance assessment, and the site criteria development. All of thse activities are generic to all waste 
forms. The closest tie is the far-field performance assessment which requires a source term as input.

The geological exploration activities are directed toward a systematic selection of the more preferable sites from among those being evaluated, based on a progressively better state of knowledge as a result of the exploration activities. Subsequently, activities will be directed toward a thorough characterization of one or more "selected" sites. The programs are using state-of-the-art, off-the-shelf techniques and are investigating media (geologic formations) that have been recommended because of properties considered favorable to waste isolation.

Data will be provided to support the calculations which indicate that geologic barriers alone are capable of providing isolation under normal circumstances (assuming models can be validated). A favorable geologic environment should be suitable regardless of the waste form.

Similarly, the earth science R\&D is improving the understanding of geologic systems as a bas is for repository qual ification. This work is described in detail in the Earth Sciences Technical PI an. (69) 


\section{IMPLEMENTATION OF SPENT FUEL DISPOSAL}

The foregoing discussion supports the conclusion that spent fuel can be a viable waste form for ultimate disposal of nuclear power wastes. The development of a basic approach to the disposal of spent fuel as waste was implemented over 10 years ago with the demonstration of emplacement and retrieval of spent fuel in the Lyons, Kansas, experimental facility. Studies have continued since that time. Immediately after the Presidential decision in April 1977 to defer reprocessing, the NWTS Program redirected its activities to more strongly emphasize spent fuel. Studies that were generic to all waste forms (e.g., geologic exploration, etc.) continued to be pursued.

A schedule for a repository development is shown in Figure 12 which is time-scaled appropriately for both Strategies II and III of the IRG Report on Waste Management. This $p l a n$ is predicated upon the disposal of spent fuel. However, it should be noted that it is equally compatible with the disposal of processed high-level waste. This is consistent with the NWTS objective of establishing safe isolation of any type of high-level waste for as long as it remains hazardous. It should also be noted that this schedule requires the availability of significant away-from-reactor (AFR) storage capacity for spent fuel to relieve impending storage capacity shortages at domestic utilities.

The general approach to disposal of spent fuel is based upon subjecting the fuel to those processing steps which are required for suitable encapsulation, with consideration given to safety, economics, and ease of system operation. The activities involved in the establishment of a waste isolation system for spent fuel include (but are not necessarily limited to): development of $\mathrm{plans,} \mathrm{establishment} \mathrm{of} \mathrm{specifications,} \mathrm{site} \mathrm{selection,}$ equipment and facility design, license application, construction, and operation. Each of these activities are themselves made up of numerous sub-activities.

In terms of spent fuel isolation, the "Waste Packaging Technology Plan" (in preparation) will be the key plan for it will define the program for development of all waste packages including the spent fuel package. The program defined is considered to be comprehensive and responsive to the national policy for disposal of spent nuclear fuel wastes. 


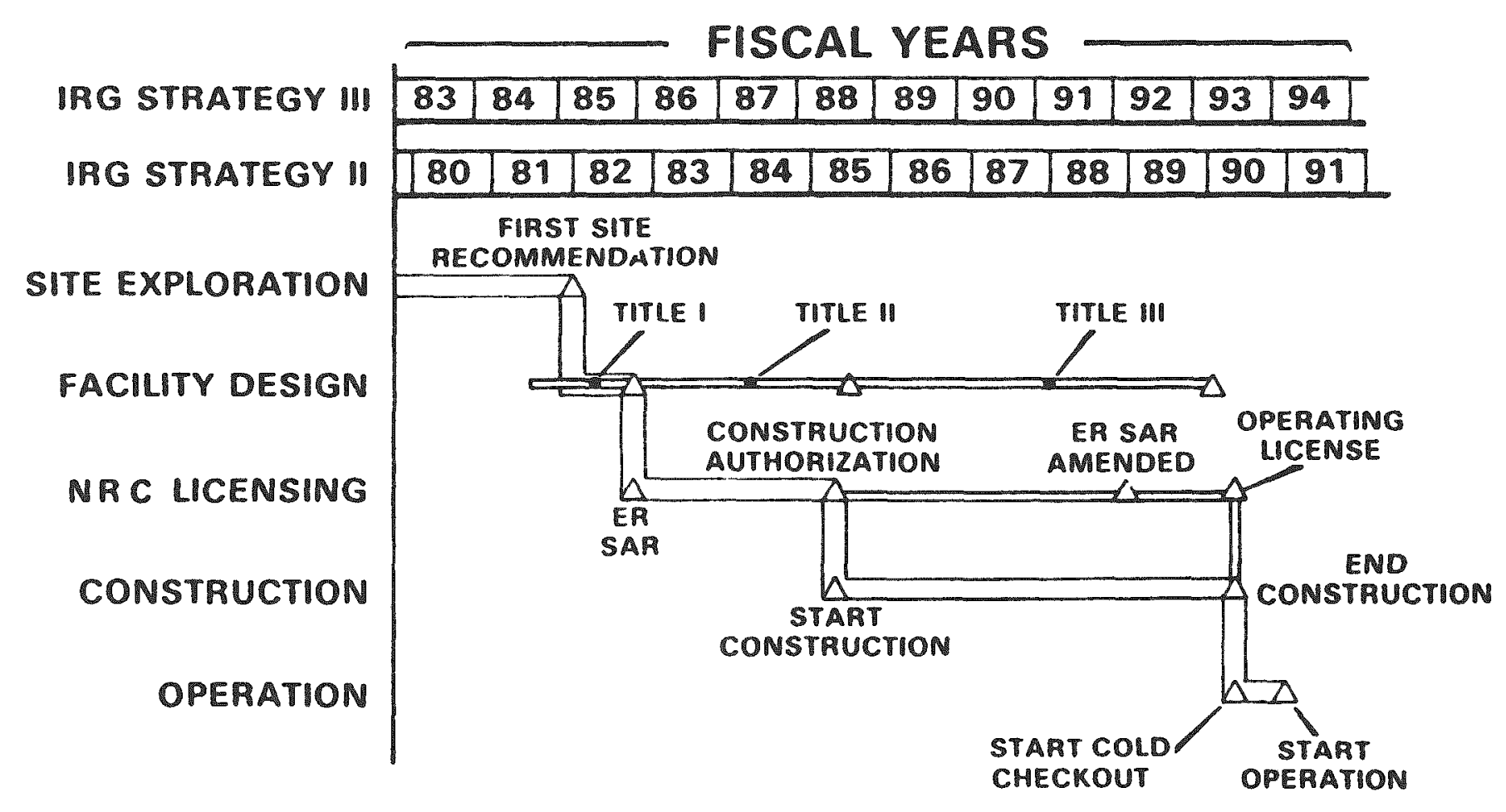

FIGURE 12. FIRST NWTS REPOSITORY PLAN FOR IRG STRATEGIES II AND III

(see reference 73 for definition of strategies) 


\section{REFEREMCES}

1. Interagency Review Group, "Report to the President by the Interagency Review Group on Nuclear Waste Management", TID-29442, March, 1979, pages 9-10.

2. Committee on Waste Disposa1, Division of Earth Sciences, "Disposal of Radioactive Wastes on Land" "National Academy of Sciences - National Research Council Publication 519, Apri1, 1957, page 6.

3. Interagency Review Group, "Report to the President by the Interagency Review Group on Nuclear Waste Management", TID-29442, March, 1979, page 4.

4. Bradshaw, R. L., and McClain, W. C. editors "Project Salt Vauit: A Demonstration of the Disposal of High-Activity Solidified Wastes in Underground Salt Mines", ORNL-4555, Oak Ridge National Lab., Apri1, 1971.

5. Interagency Review Group, "Report to the President by the Interagency Review Group on Nuclear Waste Management", TID-29442, March, 1979, page 3.

6. Atomic Energy Commission, Draft Environmental Impact Statement, WASH-1539, September, 1974.

7. Department of Energy Draft Environmental Impact Statement: Management of Commercially Generated Radioactive Waste, DOE/EIS-0046D, April, 1979.

8. Ford, President G., October, 1976, reported in the New York Times, October 29, 1976, Section I, page 10, column 2.

9. Carter, President J., April 7, 1977, reported in the New York Times, April 8, 1977, Section IV, page 1, column 1.

10. Ad Hoc Panel of Earth Scientists, The State of Geological Knowledge Regarding Potential Transport of High-Level Waste from Deep Continental Repositories, U.S. Environmental Protection Agency, EPA/520/4-78-004 TJune, 1978).

11. Bredehoeft, J. S., et a1., "Geologic Disposal of High-Level Radioactive Wastes--Earth Science Perspectives", U.S. Geological Survey Circular 779 (1978).

12. Panel on Rock Mechanics Problems that Limit Energy Resource Recovery and Development, U.S. National Committee for Rock Mechanics National Research Counci7, Limitations of Rock Mechanics in Energy Resource Recovery and Development, National Academy of Sciences (1978). 
13. Report to the American Physical Society by the Study Group on Nuclear Fuel Cycles and Waste Management, Reviews of Modern Physics, Vol. 50, No. 1, Part II (January, 1978), pages S121-128.

14. U.S. Department of Energy, Directorate of Energy Research, "Report of Task Force for Review of Nuclear Waste Management, DRAFT,", DOE/ER-0004/D (February, 1978).

15. Greene, E. M. and Jacobson, L. D. "Spent Fuel Handling and Package Program Subtask 1.4 Centralized Fuel Data Preliminary Report", TC-1076, Hanford Engineering Development Laboratory, April, 1978.

16. Storch, S. N. and Prince, B. E., "Assumptions and Ground Rules Used in Nuclear Waste Projections and Source Term Data", ONWI-24, Union Carbide Corporation, September, 1979, Appendix A.

17. Almassy, M. Y., "Spent Fuel Performance Prediction Model Development Plan for Geologic Disposal". TC-1393, Hanford Engineering Development Laboratory, May, 1979.

18. Claiborne, H. C. and Gera, F. "Potential Containment Failure Mechanisms and Their Consequences at a Radioactive Waste Repository in Bedded Salt in New Mexico", ORNL-TM-4639, Oak Ridge National Laboratory, Oak Ridge, TN (1974).

19. Burkholder, H. C., Cloninger, M. O., Baker, D. A., and Jansen, G., "Incentives for Partitioning High-Level Waste", Nuclear Technology, 31, 202 (1976).

20. Hi11, M. D. and Grimwood, P. D. "Preliminary Assessment of the Radiological Protection Aspects of Disposal of High-Level Waste in Geologic Formations", NRPB-R69, National Radiological Protection Board, Harwe 11, U.K. (1978).

21. Logan, S. E. and Berban, M. C., Development and Application of a Risk Assessment Method for Radioactive Waste Management, EPA 520/6-78-005, U.S. Envirnmental Protection Agency Office of Radiation Programs, Washington, DC (1978).

22. Katayama, Y. B. and Mende1, J. E., "Leaching of Irradiated LWR Fuel Pellets in Dionized Water, Sea Brine, and Typical Ground Water" PNL-SA-6416, Pacific Northwest Laboratories, December, 1977.

23. Department of Energy Draft Environmental Impact Statement: Management of Commercially Generated Radioactive Waste, DOE/EIS-0046D, Apri1, 1979, Appendices $J$ and $K$.

24. Bechtel National. Inc. "An Assessment of LWR Spent Fuel Disposal Options", ONWI-39, July, 1979. 
25. Interagency Review Group, "Report to the President by the Interagency Review Group on Nuclear Waste Management", TID-29442, March, 1979, page D-24.

26. Alexander, C. W., Kee, C. W., Croff, A. G., and Blomeke, J. 0., "Projections of Spent Fuel to be Discharged by the U.S. Nuclear Power Industry", ORNL-TM-6008, Oak Ridge National Laboratory, October, 1977.

27. Department of Energy, "Spent Fuel Storage Requirements - The Need for Away-From-Reactor Storage", DOE-ET-0075, February, 1979.

28. Wurm, K. J. and O'Hara, F. A., "Spent Fuel Processing and Packaging Options", paper presented at the American Nuclear Society Annual Meeting, June 3-8, At lanta, Georgia.

29. Kaiser Engineers, "A National Waste Terminal Storage Repository in a Bedded Salt Formation for Spent Unreprocessed Fuel", Kaiser Engineers Report No. 78-57-RE, prepared for DOE Oak Ridge Operations Office, December 1978.

30. Rockwe11 International, "Commercial Waste Packaging Program Radioactive Waste Package Acceptance Criteria", RHO-CD -568 , October, 1978.

31. RHO-SH-102, "Spent Fuel Storage and Isolation", Rockwell Hanford Operations, February, 1979.

32. Westinghouse Advanced Energy Systems Division, "Spent Fuel Test Climax Program Spent Fuel Canister Design Report", 79-028, January, 1979.

33. Westerman, R. E. "Draft Preliminary Conceptual Designs for Advanced Packages for the Geologic Disposal of Spent Fuel", PNL-2990, Apri1, 1979.

34. Karn-Bransle-Sakerhet, "Handling and Final Storage of Unreprocessed Spent Nuclear Fue1, Volume 1". General undated 1978 report.

35. Claiborne, H. C. and Rickertsen, L. D., "Expected Repository Conditions", paper presented at the ONWI Annual Information Meeting, October 31-November 2, 1979.

36. Anderson, R. T., "Light Water Reactor Spent Fuel Transportation Systems", AGNS-1040-1.3-47, October, 1978.

37. Stearns Roger Engineering Co., "National Waste Terminal Storage Repository for Storing Reprocessing Wastes in a Dome Salt Formation", prepared for DOE under contract EY-77-C-05-5367, January, 1979.

38. Rockwell Hanford Operations, Preconceptual Design Report, RHO-BWI-CD-35. 
39. Department of Energy Draft Environmental Impact Statement - Waste Isolation Pilot Plant, DOE/EIS-0026-D. Apri1, 1979.

40. Ramspott, L. D., Ballou, L. B., et al., "Technical Concept for a Test of Geologic Storage of Spent Reactor Fuel in the Climax Granite, Nevada Test Site", Lawrence Livermore Laboratory, University of California, Livermore, CA, UCRL-52796, June 15, 1979.

41. Fairchild, P. D. and Jenks, G. H., Avery Island - Dome Salt In Situ Test, Y/OWI/TM-551, June 15, 1978.

42. Board, M. P. and Marron, J. F., "Near-Surface Test Facility (NSTF) Test Plan", RHO-BWI-CD-15, December, 1977.

43. Brandstetter, A., Harwe 11, M. A., Benson, G. L., Bradley, D. J., Raymond, J.R. and Serne, R. J., Office of Nuclear Waste Isolation Technical Progress Report for the Quarter January 1 - March 31, 1979, ONWI-9(2), pages 124-164.

44. Bechtel Nationa1, Inc., "An Assessment of LWR Spent Fuel Disposa1 Options", Chapter 6, ONWI-39, July, 1979.

45. Interagency Review Group, "Report to the President by the Interagency Review Group on Nuclear Waste Management", TID-29442, March, 1979, page 50.

46. Department of Energy Draft Environmental Impact Statement: Management of Commercially Generated Radioactive Waste, DOE/EIS-0046D, April, 1979, pages 3.1.132-3.1.136.

47. Stearns-Roger Engineering Co. and Kaiser Engineers, "National Waste Terminal Storage Repositories 1 and 2: Cost Estimate Reconcilation Study", August, 1979.

48. Technical Support for GEIS: Radioactive Waste Isolation in Geologic Formations, Volume 1-23, Y/OWI/TM-36/1 to 23, Apri1, 1978.

49. Department of Energy, "Preliminary Estimates of the Charge for Spent-Fuel Storage and Disposal Services", DoE/ET-0055, JuTy, 1978.

50. Department of Energy, "Nuclear Waste Management Program Summary Document", DOE/ET-0094, Apri 1, 1979.

51. ONWI, National Waste Terminal Storage Program: Office of Nuclear Waste Isolation Technical Program Plan - Technical Overview, ONWI-19, February 16, 1979.

52. Deju, R. A., (Basalt) Waste Isolation Program Plan, RHO-CD-132 )Rev.), Apri1, 1978. 
53. Department of Energy Quarterly Report, Nevada Nuclear Waste Storage Investigations, NVO-196-1 to 10 .

54. Dennis, A. W., Milloy, J. A., Schully, L. W., Shefelbine, N. C., Steinebaugh, R. E., and Wowak, W. E., "Revised Concept for the Waste Isolation Pilot Plant", SAND-78-1596, July, 1978.

55. ONWI, FY 1980 Budget and Program Review for U.S. DOE Office of Nuclear Waste Management by Battelle's Office of Nuclear Waste Isolation. August, 1979 .

56. Moore, E. L. and Calmus, D. B. (Preliminary), Radioactive Waste Package Acceptance Criteria, RHO-CD-568, October, 1978.

57. Bryant, E. A. and Norris, A. E., "Fission Product Release", part of Technical Progress Report for the Quarter January 1 - March 31, 1979, ONWI-9(2), pages 90-98.

58. Brookins, D. G., "Lanthanide and Actinide Migration from Oxidized Uranium Deposits", invited paper presented at the Western Annual Meeting of the American Geophysical Union, December 7, 1978, San Francisco.

59. Witherspoon, P. A. and Degerman, 0. Technical Report No. 1, "Swedish-American Cooperative Program on Radioactive Waste Storage in Mined Caverns, Program Summary", LBL-7049, May, 1978.

60. Krumhans 1, J. L, Preliminary Resuits Report Conasauga Near-Surface Heater Experiment, SAND 79-0745, June, 1979.

61. Dames and Moore, NWTS In-Situ Test Needs Workshop of August 29-30, 1978, ONWI-7, Appendix A, pages 119-127, December, 1978.

62. Dames and Moore, NWTS In-Situ Test Needs Workshop of August 29-30, 1978, ONWI-7, December, 1978.

63. Jefferson, R. M.. Transportation Technology Center Multiyear Program Plan, TTC/002A, Sandia Laboratories, September, 1979.

64. Talbert, D. M., editor, "Seabed Disposal Program Annual Report - January to December, 1977", Sandia Laboratories, SAND 78-1359, January, 1979.

65. Banister, R. M., et a1. "Geologic Storage of Nuclear Wastes in Deep Drilled Holes", Holmes and Narver, Inc., August, 1978, HN 1531-1.

66. "Concept Definition Document for Defense Nuclear Waste Disposal in Space", Battelle's Columbus Laboratories for NASA Marsha11 Space Flight Center, October 23, 1978. 
67. Croff, A. G., et al., "A Preliminary Assessment of Partitioning and Transmutation as a Radioactive Waste Management Concept", ORNL-TM-5808, September, 1977.

68. Department of Energy Draft Environmental Impact Statement: Management of Commercial7y Generated Radioactive Waste, DOE/EIS-0046D, Apri1, 1979, Section 3.4.

69. Office of Nuclear Waste Management and U.S. Geological Survey Draft Earth Science Technical Plan for Mined Geologic Disposal of Radioactie Waste, TID-29018 (Draft), January, 1979.

70. Nowak, E. J., "The Backfill Barrier as a Component in a Multiple Barrier Nuclear Waste Isolation System", SAND-79-1109, Sandia Laboratories, October, 1979.

71. Braithwaite, J.W. and Molecke, M. A., "High-Level Waste Canister Corrosion Studies Pertinent to Geologic Isolation", SAND-78-2111, Sandia Laboratories, December, 1978.

72. SAND-77-0274, WIPP Conceptual Design Report, Sandia Laboratories, June, 1977. 


\section{BIBLIOGRAPHY}

R. G. Wymer, "Technology of the Light Water Reactor Fuel Cycle", CONF-790332-1, Nuclear Fuel Cycle Information Workshop, Oak Ridge, TN, March 13, 1979, page 147.

A. M. Platt, J. L. MCElroy, "Management of High-Level Nuclear Wastes", PNL-SA-7072, 2. Pacific Basin Conference, Tokyo, Japan, September 24, 1978, page 28.

R. Gelin, "Leaching from Irradiated Nuclear Fuel by Direct Disposal", KBS-TR-13, Kaernbraens les aekerhet, Stockholm, Sweden, June, 1977, page 18.

"Report on the Waste Management Center Planned in the Federal Republic of Germany for Spent Fuel Elements from Nuclear Power Plants", DOE-TR-7, page 91.

A. M. Platt, R. E. Rhoads, R. J. Hall, L. D. Williams, W. A. Brobst, L. B. Shappert, R. M. Jefferson, "United States Experience in the Transportation of Radioactive Materials", EDB-050900, International Conference on Nuclear Power and Its Fuel Cycles, Salzburg, Austria, May 2, 1977, page 10.

S. Stence 1, "Nuclear Waste Disposal", Ed. Res. Rep., Volume 21, No. 11, December 3, 1976, pages 885-906.

R. M. Jefferson, L. L. Bonzon, "Available Packaging and Transportation Systems", SAND-76-5544, International Symposium on Management of Waste from the LWR Fuel Cycle, Denver, CO., July 11, 1976, page 53.

"Alternatives for Managing Wastes from Reactors and Post-Fission Operations in the LWR Fuel Cycle, Vol. 1. Summary: Alternatives for the Back of the LWR Fuel Cycle Types and Properties of LWR Fuel Cycle Waste Projections of Waste Quantities; Selected Glossary", ERDA-76-43 (Vol.1), Battelle Pacific Northwest Laboratories, Richland, WA, May, 1976, page 161.

J. M. Hendrie, "Near-Term Prospects in Nuclear Regulation", AWARE, No. 100, January, 1979, pages 13-15.

S. H. Suther 1and, G. C. Allen, Jr., "High Level Defense Waste and Spent Fuel Characterization for Geologic Waste Repositories", SAND-78-1289C, ANS Meeting, Washington, DC, November 12, 1978, page 6.

"Global Spent Fuel Logistics Systems Study, Vo1. 1. GSFLS Summary Report", SAN-1583-1, Boeing Engineering and Construction Co., Seattle, WA, June, 1978 , page 468.

L. Busch, A. J. Zielen, S. J. S. Parry, "Economic Impacts of the Total Nuclear Waste Management Program Envisioned for the United States", CONF-780316-11, Waste Management Fuel Cycles Conference, March 5, 1978, page 17. 
A. L. Boch, R. K. Kibbe, "Waste Repository in a Geologic Formation", Trans. Am. Nucl. Soc., Vol. 28, pages 82-83, June, 1978.

R. T. Anderson, D. G. Carr, W. L. Godfrey, R. B. Keely, R. C. Lusk, R. W. Peterson, J. L. Ridihalgh, F. A. Sha110, M. Young, "Current Status and Future Considerations for a Transportation System for Spent Fuel and Radioactive Waste", Y/OWI/SUB-77/42513, Allied-General Nuclear Services, Barnwe 11, SC, page 481, February, 1978.

N. Kjellbert, "Radionuclide Inventories in PWR Spent Fuel and High-Level Waste Calculated by Use of the Origen Code", KBS-TR-01, Kaernbraens les aekerhet, Stockholm, Sweden, April, 1977, page 68.

D. S. Joy, B. D. Holcomb, "Logistics Models for the Transportation of Radioactive Waste and Spent Fuel", ORNL/TM-6192, Oak Ridge National Laboratory, Oak Ridge, TN, March, 1978, page 54.

"Conceptual Designs of Radioactive Canister Transporters", Y/OWI/SUB-78/16538, FMC Corporation, Santa Clara, CA, Engineered Systems Division, February, 1978, page 225.

M. K. White, R. L. Enge 1, "Comparison of Spent Fue 1 Management Fee Collection Alternatives", PNL-2826, Battelle Pacific Northwest Laboratories, Richland, WA, January, 1978, page 52.

W. B. Andrews, R. A. Burnett, R. L. Enge l, "Transportation Logistics for Spent-Fuel Storage and Disposal", 1978 Winter Meeting of American Nuclear Society, Washington, DC, November 12, 1978.

"Corrosion Resistance of Copper Canisters for Final Disposal of Spent Nuclear Fuel", KBS-TR-90, Kaernbraensles aekerhet, Stockholm, Sweden, March, 1978, page 165.

L. J. Jardine, M. J. Steindler, "Some Thermal Analysis Aspects of Metal Encapsulated Wastes", CONF-780304, ANS: Back End of the LWR Fuel Cycle, Savannah, GA, March 19, 1978, pages XI.23-XI.25.

A. R. Sattler, "Final Report of the Nine-Month Visit to the Institut Fuer Tieflagerung and the ASSE Repository", SAND-78-0366, Sandia Laboratories, Albuquerque, NM, May, 1978, page 88.

E. Albrecht, M. J. Hagen, K. Kuehn, "Disposal of Nuclear Wastes", 2. Internatinal Fair and Congress on Techniques in Environmental Protection Duesse 1dorf, F.R. Germany, February 8, 1977, page 7.

J. O. Blomeke, D. E. Ferguson, A. G. Croff, "Disposal of Spent Fuel", CONF-780316-4, Waste Management Fuel Cycles, Tucson, Arizona, March 5, 1978 , page 19 . 
B. L. Houser, C. F. Holoway, D. G. Madewe11, "Guide to Radioactive Waste Management Literature", ORNL-5226, Oak Ridge National Laboratory, Oak Ridge, TN, October, 1977, page 345.

"Nuclear Fuel Reprocessing and High Level Waste Disposal: Informational Hearings, Vol. XV, Nuclear Safeguards, Proliferation, and Alternate Fuel Cycles, Part 3", NP-22631/15/3, California Energy Resources Conservation and Development Commission, Sacramento, CA, June 16, 1977, page 711.

"Nuclear Fuel Reprocessing and High Level Waste Disposal: Informational Hearings, Volume VI, Reprocessing, Part 3", California Energy Resources Conservation and Development Commission, Sacramento, CA, NP-22631/6/3, March 10, 1977, page 361.

"Management and Storage of Commercial Power Reactor Wastes", ERDA-76-162, Energy Research and Development Administration, Washington, DC, 1976, page 39.

H. 0. Haug, "Production, Disposal, and Relative Toxicity of Long-Lived Fission Products and Actinides in the Radioactive Wastes from Nuclear Fuel Cyc les", ORNL-TR-4302, Kernforschungszentrum Kar 1sruhe, Germany, Inst. Fuer Heisse Chemie, September 26, 1975, page 190.

M. Levenson, M. Zifferero, "Public Issues of Fuel Reprocessing and Radioactive Waste Disposal", Nucl. News, Volume 20, No. 2, pages 45-48, February, 1977.

L. Koch, "European Programmes in Waste Management (Incineration) of Actinides", IAEA-186, Advisory Group Meeting on Transactinium Isotope Nuclear Data, Karlsruhe, F.R. Germany, November 3, 1975, pages 191-200.

K. Kuehn, J. Hamstra, "Geologic Isolation of Radioactive Wastes in the Federal Republic of Germany and the Respective Program of the Nether lands", CONF-760701, International Symposium on Management of Waste from the LWR Fue1 Cycle, Denver, CO, July 11, 1976, pages 580-600.

"Spent Nuclear Fuel and Radioactive Waste, Part 1. Report from the Aka-Investigation", Allmaenna Foer lacet, Malmoe, Sweden, Apri1, 1976.

"Spent Nuclear Fuel and Radioactive Waste, Part 2. Report from the Aka-Investigation", Allmaenna Foer lacet, Malmoe, Sweden, Apri1, 1976.

A. G. Croff, "Actinide Transmutation Studies: A Review", Trans. Am. Nucl. Soc., Volume 23, page 545, June, 1976.

"Alternatives for Managing Wastes from Reactors and Post-Fission Operations in the LWR Fuel Cycle, Vol. 3, Alternatives for Interim Storage and Transportation", ERDA-76-43 (Volume 3), Battelle Pacific Northwest Laboratories, Richiand, WA, May, 1976, page V. 
H. E. Kippek, C. R. Schuller, "Legal, Institutional and Political Issues in Transportation of Nuclear Materials at the Back End of the LWR Nuclear Fuel Cycle", PNL-2457, Battelle Human Affairs Research Center, Seattle, WA, March, 1979, page 188.

W. Hafemeister, "Nonproliferation and Alternative Nuclear Technologies", Technol. Rv., Volume 81, No. 3, January, 1979, pages 58-62.

V. Pasupathi, A. Parsons, R. W. Klingensmith, "In-Cell Welding Techniques for Irradiated Fuel Rods", CONF-7811109, Trans. Am. Nucl. Soc. "Volume 30, 1978, pages 783-783.

G. Carleson, "Safety Evaluation of Processes for the Encapsulation of Irradiated Fuel Elements", KBS-TR-65, Kaernbraens lesaekerhet, Stockholm, Sweden, January, 1978, page 63.

"Shipments of Nuclear Fuel and Waste: Are They Really Safe", DOE/EV-0004/2, Department of Energy, Washington, DC, Division of Environmental Control Technology, August, 1978, page 14.

L. Mollon, "Container Configuration for Storing Spent Nuclear Fuel Elements", Brooks and Perkins, Inc., Southfield, MI, Patent No. 2,700,520 (German), January 14, 1977, page 17.

C. Salander, "Concept of the German Electric Power Industry for the Disposal of Spent Fuel from Nuclear Power Plants", Kerntechnik, Volume 20, No. 5, May, 1978, pages 229-237.

S. Amelinckx, P. Dejonghe, "Working Group 8: Fuel Cycle", INIS-MF-4198, Centre D'Etude de L'Energie Nucleaire, Brussels, Belgium, March, 1976, page v.

G. J. MCCarthy, M. W. Grutzeck, "Preliminary Evaluation of the Characteristics of Nuclear Wastes Relevant to Geologic Isolation in Basalt", RHO-C-12, Atomics International Division, Richland, WA, Rockwell Hanford Operations, May, 1978, page 33.

D. R. Smith, J. M. Taylor, "Analysis of the Radiological Risks of Transporting Spent Fuel and Radioactive Wastes by Truck and by Ordinary and Special Trains", SAND-77-1257, Sandia Laboratories, Albuquerque, NM, June, 1978, page 35.

"Transport of Radioactive Materials". IAEA, Vienna, Austria, 1977, pages 225-240.

"Cost Data, Assumptions, Constraints and Other Factors Related to Economic Analyses", IAEA, Vienna, Austria, 1977, pages 271-284.

F. K. Hare, "Nuclear Wastes and the Hydrologic Cycle", Bulletin American Meteor1. Soc., Volume 59, No. 3, March, 1978, pages $267-268$. 
P. Stoll, "Completion of the Fuel Cycle in Small Countries", CONFN-770323-5, Reactor Congress, Mannhein, F.R., Germany, March 29, 1977, page 7 .

"Ceramic Encapsulation of Spent Nuclear Fuel", Energie, Volume 29, No. 3 , March, 1977, page 89.

H. Keese, "Transport of Irradiated Fuel Elements and Radioactive Waste", At. Strom, Volume 23, No. 1, January, 1977, pages 12-15.

G. H. Jenks, "Maximum Acceptable Temperatures of Wastes and Containers During Retrievable Geologic Storage", Y/OWI/TM-42, Union Carbide Corporation, Oak Ridge, TN, Office of Waste Isolation, August 17, 1977, page 7.

"Completing the Nuclear Fuel Cycle", Combustion, Volume 28, No. 12, June, 1977, pages $34-39$.

J. F. Fletcher, "HEDL Contribution to SRL Fuel Recycle Program. Quarterly Report, January-March, 1977", HEDL-TC-902-1, Hanford Engineering Development Laboratory, Richland, WA, August, 1977, page 44.

S. A. Mayman, W. W. Morgan, "Fuel Cycle Wastes: The Canadian Program", Atomic Energy of Canada Ltd., Pinawa, Manitoba, 1975, pages 138-152.

C. V. Hodge, J. E. Campbel1, "Calculations of Radiological Consequences from Sabotage of Shipping Casks for Spent Fuel and High-Level Wastes", PB-267377, Nuclear Regulatory Commission, Washington, DC, Division of Fuel Cycle and Material Safety, February, 1977, page 23.

"Regional Nuclear Fuel Cycle Centres, Volume II Basic Studies, 1977 Report of the IAEA Study Project", International Atomic Energy Agency, Vienna, Austria, 1977, page 309, Report No. STI/PUB-445 (Volume 2).

F. R. Field, "Economic Analyses of LWR Fuel Cycles", DP-1360, du Pont de Nemours (E.I.) and Co., Aiken, SC, Savannah River Laboratory, May, 1977, page 42 .

"Public Comments and Task Force Responses Regarding the Environmental Survey of the Reprocessing and Waste Management Portions of the LWR Fuel

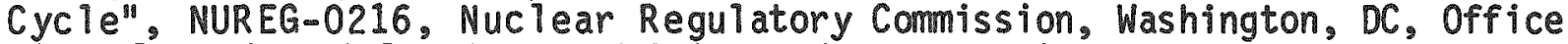
of Nuclear Material Safety and Safeguards, March, 1977, page 425.

"Interim Storage of Solidified High-Level Radioactive Wastes", TID-27189, National Academy of Sciences, Washington, DC, 1975, page 90.

A. F. Perge, "Role of Transportation in the Nuclear Fuel Cycle", Y/OWI/TM-5, Oak Ridge Y-12 Plant, TN, July 26, 1976, 23 pages, Paper 5. 
C. M. Hebb, E. T. Merrill, "Significant Actinide Activities in the LWR and LMFBR Nuclear Fuel Cycles, Final Report", PB-241674, Battelle Pacif ic Northwest Laboratories, Richland, WA, October, 1974, page 142.

"Transportation Accident Risks in the Nuclear Power Industry 1975-2020", EPA-520/3-75-023, Environmental Protection Agency, Washington, DC, Office of Radiation Programs, 1975, page 130.

W. A. Brobst, "Are Nuclear Shipments Really Safe", Environ. Lett., Volume 9, No. 4, 1975, pages 355-378.

J. E. Russe11, "Areal Thermal Loading Recommendations for Nuclear Waste Repositories in Salt", Y/OWI/TM-37, June, 1979.

G. H. Jenks, Draft, "Effects of Gaseous Radioactive Nuclides on the Design and Operation of Repositories for Spent LWRFuel in Rock Salt, ORNL-5578.

RHO-CD-506, "Spent Fuel Receiving and Packaging Facility Conceptual Design Report", Rockwe11 Hanford Operations, September, 1978.

SAND-79-0098, "WIPP Program Plan for FY 79", January, 1979.

AGNS-35900-CONF-41, "Spent Fuel Disassembly and Canning Program at the Barnwe 11 Nuclear Fue 1 Plant (BNFP)", G. A. Towns, paper presented at the ANS Winter Meeting in San Francisco, November, 1979.

AGNS-35900-1.2-45, "Spent Fue 1 Disassembly and Canning Program at the Barnwell Nuclear Fuel Plant", G. A. Towns, M. C. Rogell, and R. T. Anderson.

AGNS-35900-1.3-47, "Spent Fuel Disassembly: A Technique to Double the BNFP Storage Capability", R. T. Anderson. 
DSTIRITION LIST

ACRES AMERICAN INC ASBURGESS

ADDISON MIGH SCHOOL BUD ELLIS

AEOOSPACE CORPORATION B R FRITZ

AIF INC

TOM HUNT

ALABAMA STATE GEOLOGIST TI IOINER

ALASGA STATE GEOLOGIST R G SCHAFF

\section{ALLEO CHEMICAL CORPORATION} C M SLANSKY

ALLED GENERAL NUCLEA SERVICES K J ANDERSON P F HIGHBERGER GF MOLEN

\section{AMPEICAN FIRIROS SERVER \\ COMMITTEE \\ WILLIAM REYNOLDS \\ AMERICAN NUCLEA ENERG COUNCIL} EDWARD M DAVIS

ANALYTIC SCIENCES CORPORATION IOHN W BARTLETT

C KOPLIK

ANCO ENGINEES, INC ROBERT M WEBB

ANGELS STA TE UNUVERSTTY

CHESTER M ROWELL IR

ARGONNE NATIONAL LAMORATORY

REX COUTURE

KEVIN FLINN

ARNOLD M FRIEDMAN

LIIARDINE

IHKITTEL

ALICE PACKARD

RALPH POHTO

MSTEINDLER

OC STEWART

ARIZONA STATE GEOLOGIST HWESLEY PIERCE

\section{AMRANSAS STAIE GEOLOGIST} NORMAN F WILLIAMS

ARMAOULO COALITION OF TEXAS AMY MARTIN

ARTMUR D IITLE INCORPORATEO CHARLES R HADLOCK

ATOME ENEEGY CONTIOL ROAMD (CANADA)

IL WALLACE
ATOMIC ENERGY OF CANADA UIMTED

$P$ C FUNG

SAMAYMAN

EVA ROSINGER

TERRENCE RUMMERY

FPSARGENT

M TOMLINSON

ATOMIC ENEWG RESEA RC

ESTA WLSHMENT (UK)

D HODGKINSON

RL NELSON

HAC MCKAY

IOHN RAE

ATOMIC INDUSTRIAL FORUM

P CARRETT

AUSTRALIAN EMAESSY

R J KNIGHT

AUTOMATION INDUSTREIES INC THOMAS T BRADSHAW

TM ROBERTSON

RATTELE COLUMEUS LASORATORIES

BEVERLY AUSMUS

SANFORD BLOOM

DAVID HASTINGS

IEFF MEANS

F A O'HARA

$\checkmark$ YOUNG PARK

KENNETH S WURM

WI ZIEFFENBACH

DATTELEE SEATTEE

A HENRY SCHILLING

LIBRARY SERVICES

BAYOR UNIVETSITY

OTHAYWARD

PECMTEE NATIONAL INC

1 COLLINGS

D B CRANDALL

D S DUNCAN

C HARPER

I $B$ KEMP

CW KUHLAN

RA LANGLEY IR

NA NORMAN

HDWILLS

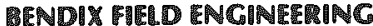

CN EDWARDS

BMA

ESTA MISHMENT (HNDIA)

KT THOMAS

PRENYMLLE PARSSM (LA)

POLCE IUIEY

OENNETT FOSTER

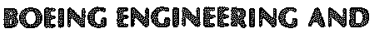

CONSTIUCTION

C PBLACK

GEORGE DYMMEL

ES KEENE
BRGEM IARLSGATAN AIA (SUEDEN)

LARS B NILSSON

ROWLANG GIEEN STATE UNIEESTIY CF KAHLE

REE 2EALE FEACTOR SAMUEL H LEVINE

RIGHAM YOUNG UNVEFESTY DEPARTMENT OF ARCHAEOLOGY KIMBALL T HARPER ROBERT L LAYTON GLENT NELSON MORRIS S PETERSON STANLEY L WELSH

TEOORRAVEN NATHONAL

LAOORATORY

RICHARD EDAVIS

A I FRANCIS

DOUGLAS HILL

PW LEVY

THOMAS LUHMAN

D MAJUMDAR

STEPHEN NICOLOS!

DONALD SCHWEITZER

K I SWYLER

HELEN TODOSOW

MOWN UNIVERSTY

G CILETI

TURNS AND MOE JOHN PIRRO

CALPONNA DEPATMMENT OF

CONSE⿱E⿰冫NATION

IAMES F DAVIS

CALPOANA RNERGY COMMISSION A I SOINSKI

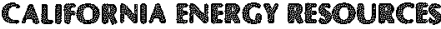
G SIMON

CAPTAL ATEEA (LA) GIOUNDWATER CONSEEVATION COMMISSION A N TURCAN

CATHOHC UNIVERSTY OF AMMEICA D D EBERT

PAUL E THIESS

CAYUGA COUNTY (NY) PLANNING

MOARD

ROBERT BROWER

IOHN SPOTO

CAYUCA LAME CONSEYVATION ASSOCHATION INC

CENTER FOA ENYIRONMENTAL INEOMMATION

ELIZABETH THORNDIKE

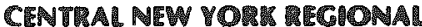
PLANNANG AND DEVEIOFMENT POA WALKER BENNING 
CITIZENS AGAINST NUCLEAR TRASH PETTUS WALLEY

CIVIL DEEENSE COUNCIL (MS) BILLY REX SHORTER

CLARION STATE COLLGE

J A LASWICK

CLEVELAND ELECTRIC ILLUMINATING COMPANY

ALBERT OBERMEYER

FRANK STEAD

CLEVELAND MUSEUM OF NATURAL HISTORY

DAVID R BUSH

COLLEGE OF ENVIRONMENTAL

SCIENCES AND FORESTRY

ROBERT HENNIGAף

COLORADO GEOLOGICAL SURVEY JOHN W ROLD

COLORADO SCHOOL OF MINES

\ COLDICH

I HUSTRLLID

COLUMBIA UNIVERSITY

WALLACE BROECKER

COMMONWEALTH ASSOCIATES INC YOSSEF BALAS

CONEERENCE OF RADIATION

CONTROL PIOGRAM DIRECTORS

HEYWARO SHEALY

CONNECTICUT OFFICE OF

POLICY AND MANAGEMENT

FAITH BRENNEMAN

TOM FITZPATRICK

CONNECTICUT STATE GEOLOGIST

HL GOF THOMAS

\section{CONAECTICUT TECHNOLOGY \\ CONSULTANTS}

C G DODD

\section{CONSERVATION AND WATER}

RESOURCES (MS)

U A WILKERSON

CONTIMOL DATA CORPORATION

RFKL ECHENBERG

\section{CORNEL UNIVERSITY}

IOHN BIRD

ARTHLR I B10OM

KBCADY

$C \triangle C A W L F$

CYNTHIA DYBALLA

JACK OLIER

ROBERT POHL

CORPORATIONS AUTHORITES AND COMMISSIONS COMMITTEE (NY)

ERUIN | LANDES
CORPORATIONS AUTHORITIES AND

PUILIC UTULITIES COMMITTEE (NV)

IAMES MCFARLAND

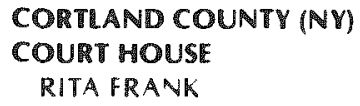

CORTLAND COUNTY (NY) HEALTH DEPARTMENT

IV FEUSS

CTH (SWEDEN)

I D LILJENZIN

DALTON-DALTON-LITTLE-NEWPORT STEVE NACHT

\section{DAMES AND MOORE}

AE AIKENSIR

ATG IIIBRARY

ROBERT R BLICK W EDEHL

SUE FINGERMAN

TODO M GATES

LIBRARIAN

RICHARD M WINAR

D'APPPOLONIA CONSULTING

ENGINEERS INCORPORATED

R D ELLISON

DE STEPHENSON

DARTMOUTH COLEGE

I B LYONS

DATA-DESIGN LABORATORIES

PROCRAM DEVELOPMENT

DAWCON

DAVID A WEBSTER

DEEP EAST TEXAS COUNCIL

OF GOVERNMENTS

REBLANKS

RLCWALKER

DELAWARE STATE GEOLOGIST

ROBERT R JORDAN

DENVER POST

BILL RITZ

DEPATTMENT OF ENVIRONMENT (UK)

AGDI $\backslash C A Q$

A T WISF

EARTH SCIENCE LABORATORY LIBRARIAL

EASTGATE DEVELOPMENT AND TRANSPORTATION AGENCY IOHAR GETCHEY

EAST TEXAS COUNCIL OF GOVERNAENTS TOM SMISER

ECOLOGICAL CENTER OF IOUISIANA INC

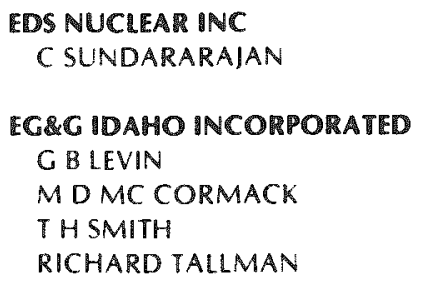

ELEKTROWATT ENGINEERING SERVICE (SWITZERLAND)

HN PATAK

ELSAM (DENMARK)

ARNE PEDERSEN

EMPORIA GAZETTE

MAX MCDOWELL

ENERGY INFORMATION CENTER ROBERT B BURTCH IR

ENERGY RESEARCH GROUP INC MARC W GOLDSMITH

ENERGY RESOURCES GROUP JAMES CLINE

ENERG SYSTEM GROUP LIBRARY

ENVIRONMENT CANADA CLAUDE BARRAUD

ENVIRONMENTAL CONSERVATION COMMITTEE (NV) G OLIVER KOPPELL

ENVIRONMENTAL EVALUATION GROUP ANN BANCROFT

ENVIRONMENTAL PLANNING LOBEY MARILYN DU BOIS

ENVIROSPHERE COMPANY

I FRANCO

II MAURO

ERIE (NY) COUNTY ENYIRONMENTAL MANAGEMENT COUNCIL IOAN P SCHMIDT

EXXON CORPORATION ARTHUR G RANDOL III

EXXON NUCLEAR COMPANY INC RANDY KIRKBRIDGE R L NEBEKER GARYWAYMIRE

FALCON RESEARCH AND DEVELOPMENT WILLIAM J GALYEAN

FIVE COUNTY (UT) ASSOCIATION OF GOVERNMENTS RHEAD $\$$ BOWMAN

FIORIDA DEPARTMENT OF NATURAL MESOURCES CHARLES W HENDRY IR 
FLORIDA POMER ANO LGHT COMPANY JAMES R TOMONTO

PAC CORPORATON MIKE WALLIS

\section{FORD BACON AND DAVIS}

DARRELL H CARD

VERN ROGERS

ARTHUR SUTHERLAND

BURTON / THAMER

POSTER MILLER ASSOCIATES

INCORPORATED

GREYL RILEY

POUNDATION SCIENCES

INCORPORATED

LOU BATTAMS

\section{FREDERIC F MELLN GEOLOGICAL. \\ ASSOCIATES \\ FF MELLEN \\ TIIENDS OF THE RATTH \\ JEFF NEWMAN \\ SALLY RODGERS \\ LORNA SALZMAN}

FSU ENYIRONMENTAL TASK FORCE SUC GENESSEO

FUGRO INCORPORATRO

I CARL STEPP

GENERAL ATOMIC COMPANY

ROBERT M BURGOYNE

G W HANNAMAN

DOUGLAS D ORVIS

IAMES N SILTANEN

RF TURNER

GEOLOGICAL SOCIETY OF AMEMICA

INCORPORATED

IOHN C FRYE

GEOLOGICAL SOCIETY OF CANADA

I CALE

B SANFORD

IS SCOTT

GEOLOGICAL SUIVEY OF SWEDEN OTTO BROTZEN

GTORGIA DEPARTMENT OF NATURAL

MESOURCES

JOHNR GEORGE

GEORGIA INSTITUTE OF TECMNOLOGY

GEOFFREY EICHHOLZ

I AWRENCE W FRY

I W POSTON

JOHN RUSSELL

CHARLES E WEAVER

GEOTECHNICAL ENGINEERS INC RICHARD W TURNBULL

\author{
GESELSCMATT PUR KERAFORSCMUNG \\ MBSH \\ HELMUT KRAUSE \\ GIBBS \& HILL \\ JACK BADMAN \\ GHLEER/COMMONWEALTH \\ I L ELLIS \\ GOOOVEA ATOMIC CORPORATION \\ DENAIS WILLIAMS \\ HAHN-MEITAER INSTITUT PUR \\ KERNFORSCHUNG BEFLN \\ IOACHIM SCHNEIDER \\ MANFORD ENGINEERING DEVELOPMENT \\ LABORATORY \\ R L KNECHT \\ HARYARD UNIVEMSITY \\ R SIEVER \\ HARWELL LAEONATORY (U.K.)
J D MATHER
}

HAWAII DEFARTMENT OF LAND AND

NATURAL RESOURCES

ROBERT T CHUCK

MOWARD UNIVERSITY

GEORCE FERGUSON

IAEA (AUSTRIA)

ROBERT CATTLIN

HREMAP PARISH (LA) POLCE JUEY

OLIVER L DE GRAVELLE

IDAMO BUREAU OF MINES AND

GEOLOGY

MAYNARD M MILLER

IDAHO DEPARTMENT OF

HEALTH AND WELFARE

BOB FUNDERBURC

IDAHO OFFICE OF ENERGY

WAYNE HARL

IDAHO STATE UNIVERSTTY

V HARRY CHARYULU

IIT RESEARCH INSTITUTE

E R BANCS

ILLINOIS ATOMIC ENEZGV

COMMISSION

HAP DAY

ILLANOIS STATE GEOLOGICAL SURVEY IACK A SIMON

INDHANA STATE GEOLOGIST IOHN B PATTON

INSTITUT FUR TIEFLAGEMUNG

(WW GEMMANY)

KLAUS KUHN
INSTITUTE FOR RNEEGV ANAL YSIS LIBRARY

INDUSTRAL RESEARCH/OFVIPOPMENT

INSTITUTE OR GEOPHYSICAL SCIENCES (UK)

DAVID A GRAY

INSTITUTE OF NATURAL RESOURCES ANTHONY LIBERATORE

INSTITUTO DI FISICA

MANTONINI

INTERANATIONAL ENERGY

ASSOCIATION LTO

JOHN B HENDERSON

INTERAATIONAL ENGINEERING

COMPANY INCOMPORATEO

JOHN COGAN

HEADQUARTERS OFFICE

INTEENATIONAL MESEARCH AND

EVALUATION

R DANFORD

INTEPNATIONAL SALT COMPANY

RLFRIANT

DKPAUL

IOWA STATE GEOLOGIST

STANLEY C CRANT

IOWA STATE COMMERE COMMISSION MAURICE A VAN NOSTRAND

IOWA STATE UNIVERSITY RICHARD DANOFSKY

IRT CORPORATION

R GALLOWAY

D NITTA

WE SELPH

I STOKES

IACKSON (MS) CLAMON-LEOGEI MARK SCHLEIFSTEIN

IAMES P MACLAREN LIMITED

(CANADA)

VALERIE CASSADAY

IAPAN ATOMIC ENERGY RESEARCH

INSTITUTE

TARO ITO

IOHAS MOPUINS UNIVEISTIY IARED COHON

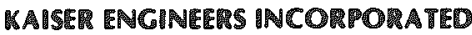
W J DODSON I SRITCHIE

IAMAN SCIENCES CORPORATION PAUL A ELLIS

MANSAS STATE GEOLOGICAL SURVEY WILLIAM W HAMBIETON 
KBS (SWEDEN)

TONIS PAPP

QENT STATE UNIVERSITY

IM COMDEN

RONALDW MANLS

\section{KENTUCKY GEOLOGICAL SURVEY} DONALD C HANEY

\section{LAKE COUNTY (OH) PLANNING COMMISSION \\ DAVID F GILMER}

LAW ENGINEERING TESTING COMPANY

I C LA BASTIE

I L GRANT

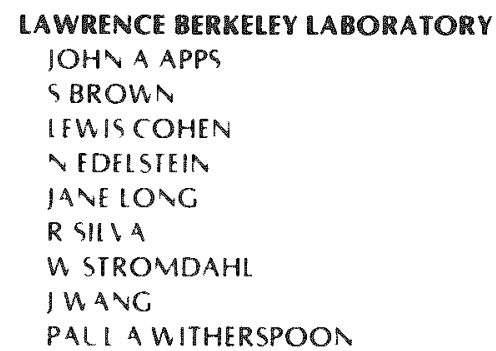

\section{LAWRENCE LIVEMMORE LABORATORY}

I B BALLOL

R) BORG

DAWIDG COLES

$A D I B A$

R FISO

$H C$ HEARD

AIFRED HOLZER IR

DAAA ISHERU OOD

FR KOVAR

CAMILLE MINICHINO

VAI-HGIEA MAO

I DRAMSPOTT

UC SL TCLIFFE

DOAAID TOWSE

LEAGUE OF WOMEN VOTERS OF OHIO I AL RA F\ANS

\section{LEHIGM UNIVERSITY}

DR SIMPSON

\author{
LOS ALAMOS SCIENTIFIC LABORATORY \\ $K$ F APT \\ I R BRIDWELL \\ I A BRYANT \\ G A CONAN \\ BRL CF R ERDAL \\ A I GAVCART \\ (I AL OF HERRICK \\ (D) HOFFMA \\ U $(11 \mathrm{TH}$ \\ AI VORRIS \\ IOF SMYTH \\ KI RT MOIFSBERC
}

LOS ALAMOS IECMNICAL ASSOCIATES INCORPORATEO

S LOCAA

\author{
LOUISIANA AIR CONTROL \\ COMMISSION \\ IAMES F COERVER

LOUISIANA DEPARTMENT OF
CONSERVATION
B JIM PORTER
RT SLTION

LOUISIANA DEPARTMENT OF

NATURAL RESOURCES

WILLIAM C HLLS

\author{
IOUISIANA DEPARTMENT OF \\ PUBLIC SAFETY \\ G U GARRISON
}

\section{LOUISIANA DEPAITIMENT OF TRANSPORTATION AND DEVELOPMENT GINO D CARLLCCIIR
LOUISIANA GEOLOGICAL SURVEY CHARLES S GROAT LEOW LOLGH

\section{LOUISIANA HOUSE COMMITTEE ON NATURALRESOURCES BILLYTAUZIN

\author{
LOUISIANA NUCLEAR ENEETY \\ DIVISION \\ LHBOHLINGER \\ LOUISIANA OFFICE OF \\ COMMERCE AND INDUSTRY \\ ANDREU F FIORES \\ RESEARCH DIVISION
}

IOUISIANA ORFICE OF SCIENCE, TECMNOLOGY AND ENVITONMENTAL POUCY

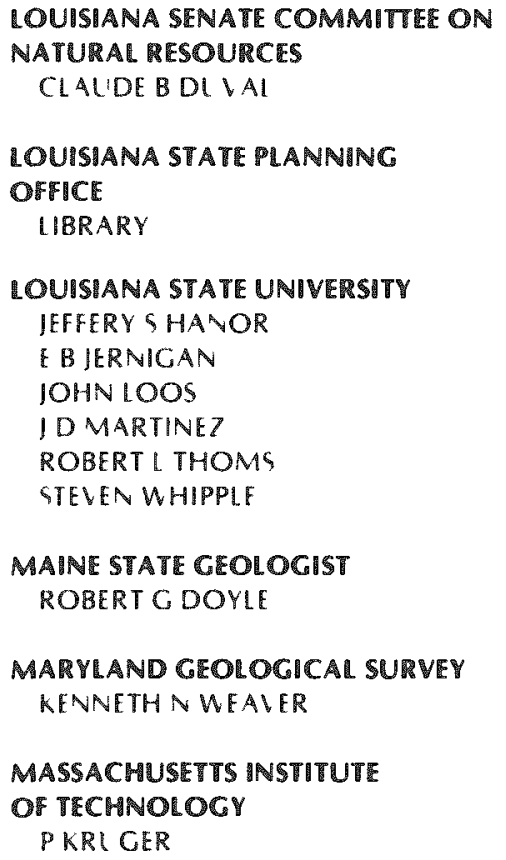

MASSACHUSETTS STATE GEOLOGIST IOSEPH A SINNOTT

MEMEES OF THE GENERAL PUELIC

ROHIT AHUIA

LINDSAY AUDIN

LILLIAN BIRD

L Z BLANKENSHIP

DAVID BOLTZ

JAMES BOYD

LARRY BRADLEY

RANDY BREWER

HAL BRODIE

A L BROKAW

DU BYERLY

CHRIS CHAPMAN

TOMMY CHESSER

HGDAVIS

IRENE DICKENSON

JOHN ROGER DRAKE

BILL DUESING

HOWARD F GANDT

SHIRLEY M GIFFORD

JOHN GLOVER

EDWIN D COEBEL

SCONZALES

A O HOBBS

CHARLES KILLGORE

IAMES A KOSTER

SCOTT KRAMER

MSKRONGELB-FANDEL

KKLANDES

IM LEAS

BRANDT MANNCMEN

NEIL MELDGIN

HARVEY W MERRELL

LOUIS MIRON

J B MUCKERHEIDE

ZORAN MUSICKI

JOHN NESBITT

EDWARD NORRIS

WILLIAM W PATTERSON IR

A M PIPER

I B ROBBINS-PENNIMAN

TERI ROLE

$M A S A B E T$

WARREN SCHADT

FRANK STEINBRUNN

KEN STOFFLET

MICHAEL LTABONY

LS TOBIAS

R P TORI

CHARLES TRAUTMANN

R I WALTERS

GEORGE WEHMAN

RICH WINDHOLZ

A HWOPSHALL IR

CHRIS ZEHREN

MICHIGAN LEGISLA HUVE OFPICE OF SCIENCE AOVISOR

GAIL MELSON

MICHIGAN STATE GEOLOGIST

ARTHUR E SLAUGHTER

MICHIGAN TECHNOLOGICAL

UNIVERESTT

I KALLIOKOSKI 
MLLLSAPS COLLECE

CHARLES SALLIS

ERIK YENSON

MINNESOTA GEOLOGICAL SURVEY

MATT 5 WALTON

MISSISSIPPI AIR AND WATER POLLUTION CONTHOL COMMISSION

CHARLEST BRANCH

CHARLES CHISOLM

MISSISSIPPY BUREAU OF

OUTDOOR RECREATION

JOSEPH W JACOB IR

MISSISSIPPI DEPA ITMENT OF

NATURAL RESOURCES

IOHN W GREEN

MISSISSIPPI ECONOMIC COUNCIL CLYDE A MCLFOD

MISSISSIPPI FUEL AND ENERGY

MANAGEMENT COMMISSION

PT BANKSTON

PETER I WALLEY

\section{MISSISSIPPI GAME AND FISH \\ COMMISSION \\ JOE STONE}

MISSISSIPPI GEOLOGICAL ECONOMIC

AND TOPOGTAPMICAL SURVEY

ALVIN R BICKER IR

WILLIAMH MOORE

\section{MISSISSIPFI OIL AND GAS \\ COMMITTEE \\ WALTER BROWN \\ DALE HARRIS FORD \\ SANFOROR STECKLER}

MISSISSIPPI MUSEUM OF NATURAL SCIENCE

NATURAL HERITAGE PROGRAM

MISSISSUPPI POWER AND LIGHT

DONALDLUTKEN

\section{MISEISSIPPI STATE BOARD \\ OF HEALTM \\ IDDIE S FUFNTE}

\section{MISSISSIPPI STATE OIL AND \\ GAS DOARO}

CLYDE R DAWIS

\section{MISSISSIPPI STATE UNIVERSITY}

BOB T CHAPIN

RICHARD A MARSHALL

ROGER SREYNOLDS

IICTOR L ZITTA

MISSISSIPPP WATER RESOURCES

OIVISION

C A SPIERS

MISEISSIPPI WULOLIEE PEDERATION

CARITON OWEN
MISSOURI GROLOGICAL SURVEY

WALLACE B HOWE

MITSUESSHL METAL CORPORATION JOAN C ABENA

MONSANTO RESEARCH CORPORATION
$K V$ GILBERT

MONTANA BUREAU OF MINES AND

GEOLOGY

SL GROFF

MORGANTOWN (WV) ENEWGY

RESEAICH CENTER

WILLIAM K OVERBEY

MUSKINGUM (OH) CONSERVANCY

DISTRICT

RAYMOND E BICHEL

NASA IOHNSON SPACE CENTER NORMAN HLBBARD

NASA LEWIS RESEARCM CENTER IACK B ESGAR

NASA MARSHALL SPACE CENTER C C PRIEST

NATIONAL ACADEMY OF SCUENCES IOHN POMEROY

NATIONAL ATOMIC MUSEUM GWEN SCHREINER

NATIONAL AUDURON SOCIETY DFDF ARMENTROUT

NATIONAL BUREAU OF STANDARDS OFFICE OF MEASUREMENTS FOR NUCLEAR TECHNOLOGY

NATIONAL SCIENCE YOUNDATION ROYALE ROSTENBACH

NATURAL RESOURCES DEFENSE COUNCIL

TR LASH

NEERASKA CONSERVATION AND SURVEY DIVISION

VINCENTH DREESZEN

NERCO

IAMESTKING

NETHERLAND SEWELL AND ASSOCIATES CLARENCF M AETHERLAND

NEVADA BUREAU OF MINES AND GEOLOGY

IOHN H SCHILLING

NEVADA DEPARTMENT OR ENERGY NOEL CLARK

NEVADA OFFICE OF PLANNING COORDINATION
NEVADA STATE PLANNING

COORDINATOR

BRUCE ARKELL

NEW MAMPSHIRE STATE GEOLOGIST GLENN W STEWARD

NEW JERSEY STATE GEOLOGIST KEMBLE WIDMER

NEW IERSEY INSTITUTE OF TECHNOLOGY BEN STEVENSON

NEW MEXICO BUREAU OF MINES AND MINERAL MESOURCES

FRANK E KOTTLOWSKI

NEW MEXICO DEPARTAENT OF ENERGY AND MINERALS

ERNEST CORIZ

LAWRENCE KEHOE

NEW MEXICO ENVIRONMENTAL EVALUATION GROUP

NEW YORK CITY DEPARTMENT OF HEALTH

LEONARD R SOLON

NEW YORK LEGISLATIYE COMMISSION ON SCIENCE AND TECHNOROGY WILLIAM B HOYT

NEW YORR STATE ASSEMPLY

HELENE CONROY

ERNIE KAARSBERC

IAN MARCEAU

WILLAM B ROYT

STANLEY STEINGUT

NEW YORK ATTORNEY GENERAL'S OFPICE

IANET Y WILLEN

NEW YORK STATE DEPARTMENT OF

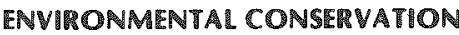
THOMAS I CASHMAN

TERRANCE P CURRAN

MELMER E WAGNER

NEW YOWK STATE ELECTRIC AND GAS CORPORATION

FSDOOUITLE

PALL ROMAR

IEWIS I STALEY

NEW YORE STATE ENERGY OFFICE

TK DE BOER

NEW YORK STATE GEOLOGICAL SUMVEY RICHARD DANA

IAMESF DAVIS ROBERT HFAKUNDINY ROBERT HFICKIES

NEW YORK STATE JONT LEGISLATIVE COMMISSION ON ENEWGY SYSTEMS ANGELO GRAZIO

NEW YORK STATE SENATE WARREN M ANDERSON 
NEW YORK UNIVERSITY

$M$ EISENBUD

NORTH CAROLINA DEPARTMENT OF NATURAL RESOURCES AND

COMMUNITY DEVELOPMENT

STEPHEN C CONRAD

GEOLOGICAL SURVEY SECTION

NORTH DAMOTA STATE GEOLOGIST LEE C CERHARD

NORTHEAST LOUISIANA UNIVERSITY JAN FULLERTON JOHN LEWIS BE PRINCE

NORTHEAST OHIO AREAWIDE COORDINATING AGENCY FREDERICK E I PIZZEDAZ

NORTHEAST OHIO FOUR COUNTY REGIONAL PLANNING AND

DEVELOPMENT ORGANIZATION R C LARLHAM

NUCLEAR ASSURANCE CORPORATION CLALDIA DRUM

CAROL THORPL

NUCLEAR ENERGY AGENCY (FRANCE) F GERA

NUCLEAR FUEL CYCLE SECTION

(W GERMANY)

M HACEN

NUCLEAR SAEETY ASSOCIATES

I A LIEBERMAN

NUCLEAR SERVICES CORPOMATION FRANCIS I KENESHEA

NUCLEAR SYSTEMS ASSOCIATES INCORPORATEO

NUCLEAR WASTE WATCMERS

HELEN LETARTE

NUS CORPORATION

W G BELTER

STELLA BREGMAN

R I DAVIS

I DI NUNNO

PH FELDHAUSEN

MI GOLDMAN

BRUCE D GUILBEAULT

PAT MACHLEDT

SL'SAN MURYHA

BARRYN NAFT

TERRY RITTER

DAVIOE RUTTER

I A STINNETT

OAK RIDGE ASSOCIATED UNIVETSITIES HCMACPHERSON

AM WEINBERC

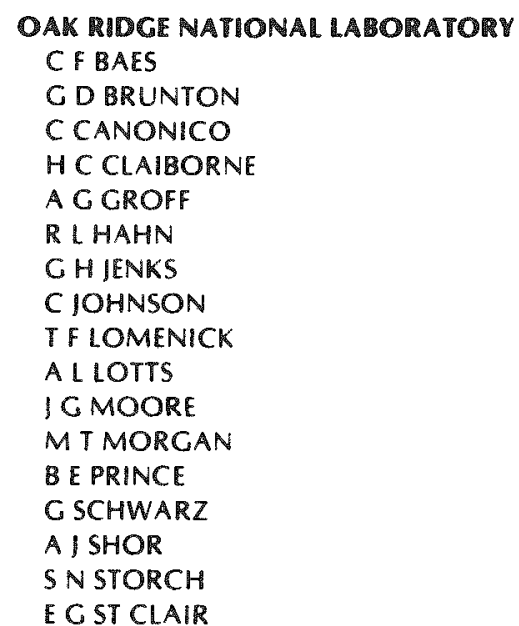

OHO AGRICULTURAL RESEARCH AND DEVELOPMENT CENTER C W DONOHO IR LIBRARY

OHIO DEPARTMENT OF ECONOMIC AND COMMUNITY DEVELOPMENT ROGER B WILLIAMS

\section{OMIO DEPAITMENT OF ENERGY}

MP KOCHMAN

ROBERT RYAN

\section{OHIO DEPARTMENT OF NATUEAL \\ RESOURCES \\ HORACE R COLLINS \\ WAYNE S NICHOLS \\ OHIO DEPARTMENT OF \\ TIANSPORTATION \\ LIBRARY \\ DAVID L WEIR}

OHIO ENVIRONMENTAL COUNCIL ERIC SMITH

OHIOEPA

IOHN NOYES

OMIO SITING COMMISSION

H KOHN

OHIO STATE UNIVERSITY

C I BLESCH

R N CHRISTENSEN

DW GEAR

M KEYHANI

F A KULACKI

WAYNE PETTYIOHN

F L'PHAM

OHO UNIVERSITY RESEARCH INSTITUTE CIRARD E KREBS

ADAM MARSH

OKLAHOMA GEOLOGICAL SURVEY CHARLES I MANKIN

ONTARIO COMPANY ROBERT BARROWS

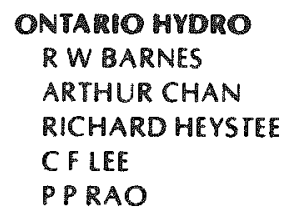

ONTARIO RESEARCH POUNDATION A D BARANYI

ORECON DEPARTMENT OF ENERGV ITAPPAN

OREGON STATE GEOLOGIST DONALD A HULL

OREGON STATE UNIVERSITY BRIAN DODD

PACIFIC GAS AND ELECTRIC COMPANY GENE BLANC

RLBLUM

PACIFIC NORTHWEST LABOMATORIES GL BENSON W F BONNER DON J BRADLEY A BRANDSTETTER

GHBRYAN L L BURGER I B BURNHAM JIM IARRET MKRIETER CR PALMER AM PLATT I R RAYMOND R JEFF SERNE R WALTER ECWATSON R D WIDRIC LD WILLIAMS

PANHANDLE-PLAINS HISTORICAL MUSEUM BILLYR HARRISON

PANHANDLE REGIONAL PLANNING COMMISSION GEORGE LOUDDER

PARSONS RENCKERMOHO QUADE AND DOUGLAS INC TR KUESEL

PB-REB INCORPORATED ME STEINER

PENASYLVANIA DEPARTMENT OF ENVIRONMENTAL RESOURCES ARTHUR A SOCOLOW

PENNSYIVANIA STATE UNIVERSTTY CHRISTINE ANDERSON IV BIGCERS DENNIS DAVIS $\checkmark N$ FIEER M GRUTZECK WILLIAM A JESTER GIMC CARTHY DMROY 
DEANE SMITH

WILLIAM B WHITE

MICHAEL ZOLENSKY

PERMIAN BASIN REGIONAL

PLANNING COMMISSION

E W CRAWFORD

PERRY COMPANY

U F BOWEN

PERRY COUNTY (MS)

BOARD OF EDUCATION

THOMAS CONMAY

I I DLNNAWAY

IOHA JORDON

IVNA LOWE

OSCAR MIXON

PIRGIM

RONALD W WILSON

PLANNING AND ENVIRONAENTAL ASSOCIATES

THOMASNIEDERKORA

POLVTECHAIC INSTITUTE OF

NEW YORK

RAPHAEL ARONSON

PORTLAND GENERAL ELECHRIC

I W IENTSCH

POTOMAC ALLIANCE

FRED MILLAR

POWER

SHFLDON DSTRAL SS

PRINCETON UNIVERSITY

HARTML IT KRL GMAW

GE PIADER

UEGLEY SHRLM

PROIECT REACH INCORPORATED ROBERT BATES

PURLC LAW UTILTIES GROUP

PURDUE UNIVERSITY

RHIOHNSON

RALLROAD COMMISSION OF TEXAS I H MORROW

RALPH M PARSONS COMPANY

AIVINE SMITH

RAYTHEON COMPANY

HIVANHOOK

REDDY COMMUNCATIONS INC IIBRARY

RENSSELAER POLYTECHNIC INSTITUTE BIMAL MAL AWIYA

RE/SPEC INCORPORATED

GDCALLAHAN

PAL I F GNIRK

U CMCCLAIN

IL VAN SAMBEEK
RIOHALGH EGGERS AND ASSOCIATES

I RIDIHALCH

ROCHESTER GAS ANO ELECTHIC

CORPORATION

LL PHILLIPS

RICHARD I WATTS

\section{ROCHESTER SAFE ENERGY \\ ALLIANCE}

ROCKWEL HANFORD OPERATIONS

HBABAD

GS BARNEY

RADEIL

B DIET?

GEORGE C EVANS

W IKL'RZEKA

CW MANRY

R A SEXTON

ROBERT SHROPSHIRE

MICHAEL I SMITH

RE SMITH

DAVE A TLRVER

DD WODRICH

DEWOOD

PA YBARRA

\section{ROCKWELL INTERNATIONAL}

CAROL IANTZEN

RHKARLSSON

R I MERLINI

HARRY PEARLMAN

HLRECHT

LAMRENCE I SMITH

RE SMITH

SANDIA LABOMATORIES

E H BECKNER

$M B E N S O N$

C L CHRISTENSEA

I F CL DERMAA

DEPARTMENT 4510

R G DOSCH

JERRY M FREEDMAN

LESLIE R HILL

THOMASE HINKEBEIN

R M IEFFERSOA

OE JONES

R D KLETT

RLINCOLN

R W LYNCH

$\$$ A MOLEKE

GFRLDOLFO

A R SATTLER

IW SCLLLY

AE STEPHEVSON

DANIEL MTALBERT

LD TYLFR

WD WEARI

WIPP CENTRAL FILES

SAN IUAN COUNTY (UT) COMMISSION

SAVANNAH RIVER LAEORATORY

IL CRANDALL

R G GARVIN

HI GROH

C HICE

\author{
FDKING \\ I W MARINE \\ W C REINIG \\ SCANDPONER INCORPORATED \\ PAMORRIS \\ SCIENCE APPLICATIONS \\ INCORPORATED \\ SOPHIE CARMAN \\ CW CRAVEN \\ RALPH FULLWOOD \\ RONALD HOFFMANN \\ DAVID H LESTER \\ JOHNE MOSIER \\ WILLIAM R RHYNE \\ DURNOT ROSS-BROWN \\ RICHARD W STAROSTECKI \\ MI SZULINSKI \\ ROBERT WILEMS \\ SCIENTIFIC RESEARCH EVALUATION \\ RONALD C CALLEN \\ SCK (BELGUM) \\ F CASTEELS
}

SENECA COUNTY (NY) OEPARTMENT OF MEALTH

BRIAN DOMBROWSKI

IILL LEVIN

SHAFER EXPLORATION COMPANY WILLIAM E SHAFER

SIERRA CLUE MISSISSIPPI CMAPTET

SIERRA CLUR NORTMEAST

OHIO GROUP

TIENKINS

SIX-COUNTY (UT) COMMISSIONERS

ORGANIZATION

LARRY I SIEBERT

SM STOLER CORPORATION

W KUPP

SOLUTION MINING RESEARCH

INSTITUTE

HDIAMOND

SOUTH CAROLANA OFFICE OF

ENERGY RESOURCES

LARRY LEFEBVRE

LAMAR PRIESTER

SOUTH CAROLNA STATE GEOLOGIST NORMAN K OLSON

SOUTH DAKOTA SCHOOL OF MINES ANO TECMNOLOGY

C J CESSNER

W GRAMS

SOUTH DAKOTA STATE GEOLOGIST

DI VCAN I MCGREGOR

SOUTMEASTERN UTAM ASSOCIATION OF GOVERNMENTS

WILLIAM K DINEHART 
SOUTHERN TIEY CENTIRAL REGIONAL

PLANNING AND DEVELOPMENT BOARD

KEVIN BYRNE

ANN CIARKE

WILLIAM D HESS

LINDLEY V PRYOR

SOUTHERN SCIENCE APPLICATIONS

KD KIREY

SOUTH PLAINS ASSOCIATION

IRLETT MAYES

COMMUNITY DEVELOPMENI

PLANNER

SRI INTERAATIONAL

R K WHITE

STANFORD UNIVERSITY

ROVALD A HOV ARD

KONRAD B KRALSKOFF

PKRL GER

IRWIN REMSON

\section{STATE UNIVERSITY COLEGE}

(CORTLAND)

DANIEL I BRENAAN

STATE UNIVEFSITY COLLGE (BUFEALO) IRUINC H TESMER

STATE UNIVESITY OF NEW YORK

(ALEANY)

KEVIV BURKE

STATE UNIVERSITY OF NEW YORK

(BNGMAMTON)

ALBERT A DEKIN IR

TW DONNELLY

1 THOMSEN

STATE UNIVERSITY OF NEW YORK

(SYRACUSE)

DONALO F BEHRENO

PFTER BLACK

ARTHUR R ESCHNER

NORMAN RICHARDS

\section{STEARNS-ROGER ENGINEERING}

COMPANY

| HIONES

STPPHEN 8 AUSTIN UNIVERSITY

JAMES E CORBIN

EIRAY NIXON

-

STONE AND WEBSTER ENGINEERING

CORPORATION

CRAIC F GROCHMAL

IPECK

DSPIERCE

\section{SUL ROSS STATE UNIVERSITY}

BARTONHW WRNOCK

SYRACUSE UNIVETSITY

LEE HARRINGTO

ERNEST HML LLER

IF ROBINSON
SYSTEMS SCIENCE AND SOFTWARE PITER LAGLS

TAYIOR WINE COMPANY
ACRICE

TENNESSEE OEPARTMENT OF

PUPLIC HEALTH

ROBERT H WOLLE

TENNESSEE ENERGY AUTHORITY

ED SPITZER

IACK THOMAS

TENAESSEE STATE GEOLOGIST

ROBERT E HERSHEY

TERPA TEK

M D VOEGELE

TEXAS ADVISORY COMMISSION

ON INTERGOVERNMENTAL RELATIONS

TEXAS A\&M UNIVERSITY

I HANDIN

ROY W HANN IR

DK PARRISH

STEPHEN RITER

J RISSSELL

JOSEPH L SCHLSTER

IIM SMATHERS

JAMES G TEER

\author{
TEXAS RUREAU OF ECONOMIC \\ GEOLOGY \\ SI DL TTOA \\ T C GUSTAVSOA \\ C R HANDFORD \\ $C \backsim$ KREITLER \\ MW PRESLEY \\ TEXAS CMRISTIAN UNIVERSITY \\ JACK L UAIPER \\ IEXAS DEPARTMENT OF HEALTH \\ IOE NANLS
}

TEXAS DEPARTMENT OF PUBLIC SAFETY

R A LANGFORD

\section{TEXAS DEPARTMENT OF WATER \\ RESOURCES \\ HARVEY D DAVK}

TEXAS ENEEGV ADVISORY COUNCIL AIVIN ASKEW

MIITONL HOLLONAY

TEXAS ENVIRONMENTAL COALITION

STHVE FRISHAMAN

TEXAS INDUSTIIAL COMMISSION

PHYLLIS PROCTER

TEXAS LIEUTENANT GOVERNOR'S ORPICE CAROL TOMBARI

TEXAS TECHNICAL UNIVERSITY

IOHA S MECHAM

BILL MEYER-OAKES
THREE RIVERS (OH) WATEMSHED DISTIEICT

GLORGE E WATKINS

IIOGA COUNTY (NY) PLANNING

BOARD

MARY SHARNON

TOMPKINS COUNTY (NV) DEPARTMENT

OF PLANNING

FRANK R LIGUORI

TOUMLL, SHUCKROW AND

ASSOCIATES

CI TOUHILL

TRENDS PUBLISHING INC.

TRW SYSTEMS AND ENERGY

E BERMAN

ER CHRISTIE

LIBRARIAN

F MERTES

HERBERT N ROSENBERG

TULANE UNIVERSITY

CHARLES CARTER

WALTER MASON

TUSREGEE INSTITUTE IRA G DILLON

UNDE GMPM

DR OLINGER

UNION OF CONCERNED SCIENTESTS BI BACKAL

UNIVEISITY OF AKRON

$R$ G CORBETT

UNIVERSITY OF ATIZONA

JAAK DAEMEN

STANIEY NDAVIS

CHARLES LYON

JAMES C MCCRAY

R G POST

ROBERTI SEALE

DAUID L SOUTH

UNIVERSITY OF CALIFORNIA (RERMELEY)

NEVILLE G W COOK

KARI SAARI

UNIVERSITV OF CALIFORNIA (LOS

ANGELES)

D OKRENT

UNIVERSITY OF OENVER

THERESA COSTELLO

UNIVETSITY OF FIORIOA

WILLIAM HELLIS

MIOHANIAN

UNIVERSTY OF CEORGIA

ID SPAL LDING

DAVID B WENNER

UNIVERSITV OR HAWAII AT MANOA

MURIIH MAUGHNANI 
UNIVERSITY OF HOUSTON JOHN R HOWELL

\author{
UNIVERSITY OF ILLINOIS \\ FRED A DONATH \\ GLENN GERDIN \\ UNIVERSITV OF INDIANA \\ I B DROSTE \\ HAYDN H MLRRAY \\ CHARLES I VITALIANO
}

UNIVERSITY OF KANSAS

LOUIS F DELWIC

UNIVEFSITY OF LOWELL

WILLIAM FILLIPONE

JOSE MARTIN

JAMES R SHEFF

UNIVERSITV OF MARYLAND

KAZGS ALMENAS

DICK DUFFEY

FRANK MUNNO

UNIVERSITY OF MICHIGAN

JOHN SKING

UNIVETSITV OF MINAESOTA

SL CROUCH

E N LINDNER

$K$ SINHA

CM ST JOHN

DHYAROLEY

UNIVERSTTY OF MISSISSIPPI

CLYDE E COOK

FREDERICK MANLEY

ED MEEK

VELON MINSHEW

MARLIN PURDIE

\section{UNIVERSITY OF MISSOUTI \\ (KANSAS CITY) \\ TRUMAN STAUFFER}

UNIVESETTY OF MISSOURI (COLUMBIA)

W D KELLER

WALTER MEYER

DARROL H TIMMONS

UNIVERSETY OF MISSOURI (ROLLA)

NICK TSOULFANIDIS

UNIVERSIT OF NEW MEXICO

DG BROOKINS

R EWING

KKEIL.

E LOGAN

DM WOOOALL

UNIVERSTY OF NORTH CA ROLNA

(CHAPEL MULL)

IAMES H CRAWFORD

UNIVERSITY OF NOTRE DAME

IOHN LUCEY

KT YANG

UNIVERSTY OF OKLAHOMA

KENNETH S JOHNSON

\author{
UNIVERSITY OF PENASYLVANIA \\ SATI SADHAL. \\ UNIVERSITY OF PITTSBURGM \\ B L COHEN \\ UNUVESITY OF RHODE ISLAND \\ EDWARD P LAINE \\ ROBERT L MCMASTER \\ UNIVERSITY OF SOUTHERN MISSISSIPPI \\ CHARLES R BRENT \\ RALPH D CROSS \\ GEORGE PASSONEY \\ OSCAR L PAULSON IR \\ IAMES W PINSON \\ US DEPARTMENT OF ENEMGY (CHICAGO) \\ RNACK \\ US DEPARTMENT OF ENERGY (DENVEI) \\ JACK O BRIEN \\ HARRY SMITH \\ US DEPARTMENT OF ENERGY (GRAND \\ [UNCTION) \\ FRANK ECKERSON \\ J ELLIS
US DEPARTMENT OF ENERGY IDAHO FALLS)
J PHAMRIC
I WHITSETT

JOHN N SKATES

UNIVERSITY OR TENNESSEE
I B FUSSELL

\section{UNIVERSITY OF TENNESSEE \\ (CHATTANOOGA) \\ WILLIAM BLACK \\ UNIVERSITY OF TEXAS AT ARLINGTON
CHARLES I SMITH}

UNIVERSTTY OF TEXAS AT AUSTIN

RICHARD ASHLEY

LF BROWN

E LINN DRAPER IR

WILLIAM L FISHER

EARNEST F GLOYNA

JOHN B CORDON

CLARK HUBBS

E C IONAS

DALE KLEIN

IOE D LEDBETTER

GWERMUND

UNIVERSITY OF UTAH

JOHN S ALLEN

DUNCAN FOLEY

FRANK C HACKMAN

$S K K A O$

ROBERT C PENDLETON

HOWARD P ROSS

GARY M SANDQUIST

EDWARD B SISSON

UNIVERSITY OF VIIEGINIA

TG WILLIAMSON

UNIVERSITY OF WISCONSIN

CHARLES W MAYNARD

JOHN B HEIL

U S COAST GUARD ACADEMY

MICHAEL HELFERT

US DEPARTAENT OF COMMERCE

LH GEVANTMAN

US OEPATTMENT OF ENERGY

(ALUQUERQUE)

D DAVIS

DORNEST SCHUELER

WIPP PROIECT
US DEPARTMENT OF ENELGY (LAS VECAS)

RO BETTERIDGE
I B COTTER
D DUNCAN
ME GATES
IR GILPIN
KN IOY
MP KUNICH
H L MELANCON
RM NELSON IR
NEVADA TECHNICALL LIBRARY
R W NEWMAN
IROBERTS
R W TAFT
TE WADE

US DEPARTMENT OF ENERGY (NEW YORK)

CHARLES BAXTER

US DEPARTMENT OF ENETGY IOAK MOGE)

TENSMINGER

DEWEY E LARGE

TECHNICAL INFORMATION CENTER

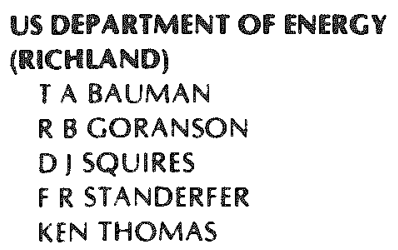

US DEPARTMENT OF ENERGY

(RICHLAND-COLUMEUS)

1 O NEFF

US DEPARTMENT OF ENERGY

(SAN FRANCISCO)

CDIACKSON

JOHN MUHLESTEIN

US DEPARTMENT OF ENERGY

(SAVANAAM RIVER)

LAWRENCE W FRY

T B HINOMAN

US DEPARTMENT OF ENERGY-PURLIC MEAOING/DOCUMENT ROOMS

ALBUQUERQUE OPERATIONS OFFICE CHICACO OPERATIONS OFFICE DOE HEADQUARTERS 
IDAHO OPERATIONS OFFICE NEVADA OPERATIONS OFFICF OAK RIDGE OPERATIONS OFFICE RICHLAND OPERATIONS OFFICE SAN FRANCISCO OPERATIONS OFFICE SAVANNAH RIVER OPFRATIONS OFFICE

RECION IX OFFICE-SAN FRANCISCO WASHINGTON DC

\section{US DEPARTMENT OF ENERGY REGION I-} BOSTON

DLANE DAY

\section{US DEPARTMENT OF ENERGY REGION \\ II-NEW YORK \\ LENORE LFDMAN}

\section{US DEPARTMENT OF ENERGY REGION}

\section{III-PHILADELPHIA}

MARIA MARKS

\section{US DEPARTMENT OF ENERGY REGION IV-ATIANTA$$
\text { DAUID ALANIZ }
$$

\author{
US DEPARTMENT OF ENERGY REGION

\section{$V$-CMICACO} \\ PHILUIP T ZENI
}

\section{US DEPARTMENT OF ENERGY REGION VI-DALLAS \\ WILLIAM NIKOLIS

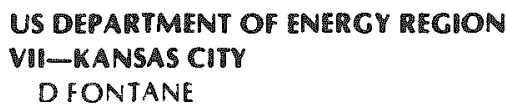

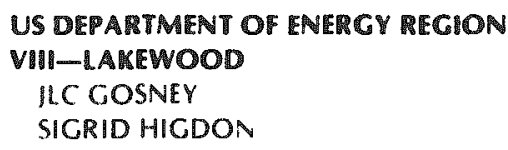

US DEPAITMENT OF ENERGY REGION IX-SAN FRANCISCO IAMES RUSSELL

\section{US DEPARTMENT OF ENERGY MEGION \\ $X$-SEATTLE \\ LIBRARY \\ LEE JOHNSON}

\begin{tabular}{|c|c|}
\hline $\begin{array}{l}\text { US DEPARTMENT OF ENERGY } \\
\text { (WASHINGTON DC) } \\
\text { W W BALLARD }\end{array}$ & $\begin{array}{l}\text { C W SHURR } \\
\text { ROBERT I TILLING } \\
\text { RD WATTS }\end{array}$ \\
\hline EL'GENE F BECKETT & \\
\hline DGBOYER & USGS-HOUSTON \\
\hline CR COOLEY & JERRY CARR \\
\hline GHDALY & \\
\hline I C DEMPSEY & USCS-ITHACA \\
\hline JOHN M DELTCH & OICOSNER \\
\hline WARREN EISTER & \\
\hline MARK W FREI & USGS-DACKSON \\
\hline CH CEORGE & E HBOSWEL \\
\hline OP GORMLEY & CHARLES A SPIERS \\
\hline R I COTTSCHALL & \\
\hline DONALD H GROELSEMA & USGS-LAREWOOD \\
\hline SLHACK & DONR MABEY \\
\hline C AHEATH & WILLIAM S TWENHOFEL \\
\hline KEITH KLEIA & RICHARD WADDEL \\
\hline
\end{tabular}

IIM LANDERS

M ILAWRENCE

ROCER LE GASSIE

IL LIVERMAN

EFMASTAL

BEN MCCARTY

SMEYERS

WE MOTT

IF MULLANEY

CARL NEWTON

CK OERTEL

A C PETTIT

MURIEL SCARBOROUGH

I E SEYMOUR

RALPH STEIN

OSCAR STRADINGER

V G TRICE

IIM TURI

D L VEITH

SUSAN WELLS

I B WORK

HHYOUNG

US EPA

S GOLDRERG

A S COLDIN

ANDREW / LETER

IAMESEMARTIN

PETER E MCCRATH

IAMES NEIMEISEL

JOHN L RUSSELL

D S SMITH

W A WILLIAMS

USCS-AUSTIN

A C WINSLIOW

USGS-BATON ROUCE

RL HOSMAN

USCS-DENVER

A H BALCH

IOHN D BREDEHOEFT

JEFFE CLEVELAND

WILIIAM W DUDLEY IR

IULES FRIEDMAN

LM GARD

ROBERT I HITE

DL HOOVER

IOHA C REED IR

ERUSH

CW SHURR

ROBERT I TILLINC

\author{
USGS-MENLO PARK \\ ID BYERLEE \\ EVERETT JENNE \\ ARTHUR H LACHENBRUCH \\ R W POTTER \\ IACOB RUBIN \\ USGS-RESTON \\ G D DEBUCHANANAE \\ ROBERT MHAMILTON \\ EUGENE H ROSEBOOM IR \\ PETER R STEVENS \\ DAVID B STEWART \\ NEWELL, I TRASK IR \\ WARREN W WOOD
}

\author{
U S NUCLEAR RECULATORY \\ COMMISSION \\ C BARTLETT \\ ORMEN E BASSETT \\ RECISR BOYLE \\ ROBERT BUDNITZ \\ MICHAEL C CULLINGFORD \\ I DAVIS \\ IAY B DURST \\ MARY A EADDEN \\ SFUCIGMA \\ W M CRAYSON \\ EOWARD FHAWKINS \\ EE HELD \\ LINDA LEHMAN \\ HELEFOURE \\ I MALARO \\ MANAGER - WASTE ENVIRONMENTAL \\ STANDARDS PROCRAM \\ IOHN B MARTIN \\ TINICKOLSON \\ EDWARD O'DONNELL \\ PROIECT OFFICER-SAFECUARDS OF \\ HLW REPOSITORIES CONTRACTS \\ E REGNIER \\ $I$ C ROBERTS \\ GARY ROBBINS \\ DM ROHRER \\ SF SCHREURS \\ SHELDON SCHWARTZ \\ SH SMLEY \\ U S NUCLEAR REGULATORY MESEARCM \\ CLYDE JUPITER \\ UTAM ENERGY OFFICE \\ IAMES M BYRNE
}

UTAM CEOLOGICAL AND MINERAL

SURVEY

DONALD T MCMILLAN

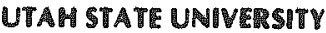

IAY C ANDERSON

IACK T SPENCE

\section{VANDEDERT UNIVES}

FRANK L PARKER

VAUCHN MANSEN ASSOCIATES

PAUL BLACKER 
VERMONI PUBLIC SERVICE DOARD

RICHARD SAL DEK

VERMONT STATE GEOLOGIST

CHARLES A RATTE

VIRGINIA STATE GEOLOGIST ROBERT C MILICI

WACO TRIBUNE-HERALD

DOL GWILLIAMSON

WASMINGTON STATE GEOLOGIST

I AL GHE LIVINGSTONIR

WASTE ISOLATION PILOT PLANT

RK BROWN

WAYNE STATE UNIVERSITY

JAMES A WOODYARD
WEBSTER PARISH (LA)

POLICE IURY

TYLON BLA VION

\section{WESTINGHOUSE ELECTRIC \\ CORPORATION \\ P BRADBLIRY \\ $A R$ HAKL \\ J HALEY \\ LIBR ARY \\ GEORGE P SABOL}

WESTINGHOUSE MANFORD COMPANY ALBERT G BLASEWITZ

WESTINGHOUSE WIPP PROIECT

CL HOHMANN

WEST VIRGINIA STATE GLOLOCIST ROBERT B ERMIN

WILLLFE MANAGEMENT INSTITUTE MLRRAY W ALTON
WISCONSIN GEOLOGICAL AND

NATURAL MISTORY SURVEY

MEREDITH E OSTROM

WISCONSIN STATE ENERGY ORPICE IOHN H THOMAN

WOODWARO-CLVDE CONSULTANTS F R CONWELL

HANS M EWOLDSEN

LIBRARY

CHARLESLTAYLOR

WYOMING STATE GEOLOGIST

DANIEL N MILLER IR

YALE UNIVERSTTY

ROBERT M GARRELS

YATES COUNTY (NV) PLANNINC

BOARD

ROBERT MCNARY 